\title{
Food-web mediated export of biogenic carbon in oceans: hydrodynamic control
}

\author{
Louis Legendre $^{1, *}$, Fereidoun Rassoulzadegan ${ }^{2}$ \\ 'Département de biologie, Université Laval, Québec, QC, Canada G1K 7P4 \\ ${ }^{2}$ Station Zoologique, BP 28, F-06230 Villefranche-sur-Mer, France
}

\begin{abstract}
This paper describes an approach to determine, using a small number of food-web or hydrodynamic variables, the partitioning of phytoplankton production among 3 carbon fluxes, i.e. remineralization within the euphotic zone, food-web transfer, and sinking to depth of organic particles. In order to do so, the flows of biogenic carbon in the marine pelagic environment are reduced to 5 broad pathways, which are ordered along a continuum of decreasing export relative to primary production. At one end of the continuum, ungrazed phytoplankton is exported to depth and, at the other, biogenic carbon is remineralized within the bacteria-microzooplankton loop. In the present paper, export of biogenic carbon from the euphotic zone includes food-web transfer of primary production and downward flux of particulate organic carbon (POC) into deep waters. A simple model and data from the literature lead to the conclusions that: (1) the export characteristics of pelagic ecosystems are largely determined by the size structure of primary production and the matching (or, conversely, segregation) between primary production and grazing and (2) total export from the euphotic zone is a function of the delivery of mechanical energy to the upper water column whereas the partitioning of total export between foodweb transfer and sinking of POC is controlled by temporal variations in depth of the surface mixed layer Food-web transfer is significant for marine resources and sinking of POC may contribute to the regulation of climate change (sequestration at depth of biogenic carbon).
\end{abstract}

KEY WORDS: Carbon flux Oceans Phytoplankton production Size Matching - Food web Hydrodynamics

\section{FLUXES OF BIOGENIC CARBON IN OCEANS: SIGNIFICANCE AND APPROACHES}

In oceans, fluxes of biogenic carbon resulting from phytoplankton production are either remineralization (i.e. respiration) within the euphotic zone or export out of it. These fluxes are independent of horizontal advection because, advected or not, biogenic carbon can only be remineralized in the euphotic zone or exported from it. Export, in the present paper, is defined as including both transfer to large animals and sinking of particulate organic carbon (POC) into deep waters. The paper does not consider the downward flux of dissolved organic carbon (DOC), in spite of its possible significance in some conditions (e.g. Carlson et al. 1994, Michaels et al. 1994), because this flux has not

•E-mail: louis.legendre@bio.ulaval.ca been quantified in most situations. These fluxes are not instantaneously coupled with phytoplankton production, as there often is transient accumulation of POC and DOC in the euphotic zone. The 2 particulate export fluxes have global socio-economic significance. Food-web export to large and long-lived animals sets an upper limit to marine renewable resources. This type of export is accompanied by respiratory losses $\left(\mathrm{CO}_{2}\right)$ of ingested carbon. Export towards deep waters is mainly through the production of fast-sinking faecal pellets and sedimentation of ungrazed algae, but it also includes other mechanisms such as vertical migrations of zooplankton (Longhurst et al. 1990), fall-out of organic debris and carcasses (e.g. Stockton \& De Laca 1982, Noji 1991), and downward mixing of DOC produced by phytoplankton. In mesopelagic (Torres \& Childress 1985, Cho \& Azam 1988) and deep waters (Childress \& Mickel 1985, Siebenaller \& Somero 1989), part of the POC is respired by heterotrophic bacteria 
and metazoans. Some of the carbon that reaches the deep ocean may become sequestered, i.e. removed from the ocean-atmosphere system for at least $100 \mathrm{yr}$ Climate changes at various time scales, including the possible ongoing global warming, may be related to (or mediated by) variations in the pool of sequestered carbon.

There are at least 3 general approaches used to quantify biogenic carbon fluxes in oceans. The first consists in determining empirical relationships between phytoplankton production and some flux. For example, concerning fisheries, Iverson (1990) has shown that a linear relationship exists between the production of carnivorous fish and squid and that of phytoplankton, for open-ocean and coastal environments. Concerning the export of biogenic carbon to depth, several authors (e.g. Eppley \& Peterson 1979 , Betzer et al. 1984, Pace et al. 1987, Wassmann 1990) have proposed empirical models (equations) describing the downward POC flux as a function of total primary production in the euphotic zone. The second approach belongs to the general category of flow models. These models simulate the flows of one or several biogenic elements (e.g. C, N) among compartments that represent trophic levels or taxonomic groups (e.g. Fasham et al. 1990) or that are based on size classes (e.g. Moloney \& Field 1991). Such models often include flows to large animals and out of the food web. The third approach aims at determining empirical relationships between some environmental variables and export of biogenic carbon. A fisheries example is the relationship determined by Cury \& Roy (1989) between the annual recruitment of several fish species and Ekman-type upwelling.

The present paper proposes an approach to determine, using a small number of food-web or hydrodynamic variables, the partitioning of phytoplankton production among 3 fluxes, i.e euphotic-zone remineralization, food-web transfer, and sinking of POC into deep waters. Equations are formulated and values of parameters are derived from observations

\section{FLUXES, POOLS, AND FLOWS OF BIOGENIC CARBON IN OCEANS}

The above 3 fluxes of biogenic carbon in oceans generally correspond to the 3 carbon pools defined by Legendre \& Le Fève (1992) on the basis of the turnover time of biogenic carbon (i.e. time elapsed between the photosynthetic uptake of carbon by phytoplankton and the return of this carbon as $\mathrm{CO}_{2}$ to the surface waters or the atmosphere). The pools are: short-lived organic carbon (turnover time $<10^{-2} \mathrm{yr}=$ 3 to $4 \mathrm{~d}$ ), long-lived organic carbon (turnover time ranging between $10^{-2}$ and $10^{2} \mathrm{yr}$ ), and sequestered biogenic carbon (turnover time $>10^{2} \mathrm{yr}$ ). Short-lived organic carbon consists of organisms with short turnover times as well as labile dissolved organic compounds and it mainly transits through microbial components of the food web. Long-lived organic carbon comprises renewable marine resources (e.g. fish, marine mammals) and also heterotrophic bacteria involved in the breakdown of organic matter derived from large heterotrophs. The latter stresses the fact that the turnover time of biogenic carbon is not the same as the doubling time of organisms which mediate the turnover, e.g heterotrophic bacteria decomposing a whale carcass may have individual doubling times $\leq 1 \mathrm{~d}$ but they are part of a carbon pool whose turnover time is tens of years. Sequestered biogenic carbon may take various forms, among which are organic remains buried in sediments (including petroleum), inorganic deposits of biological origin (e.g. calcareous ooze, coral reefs, continental limestone), refractory dissolved organic matter, and dissolved $\mathrm{CO}_{2}$ in deep waters resulting from the in situ oxidation (respiration) of organic compounds.

The sizes of marine phytoplankton cover almost 4 orders of magnitude, from ca $2000 \mu \mathrm{m}$ (diatom Ethmodiscus rex, in warm oceanic waters) down to $0.6-0.7 \mu \mathrm{m}$ (ubiquitous prochlorophytes). In addition, photosynthetic products include dissolved organic matter exuded by phytoplankton. For simplicity, the size range of primary production is divided here into 3 classes: large phytoplankton ( $\mathrm{L}:>5 \mu \mathrm{m}$ ), small phytoplankton (S: 0.2 to $5 \mu \mathrm{m})$, and DOC $(<0.2 \mu \mathrm{m})$. Although marine microbiologists normally separate bacterioplankton from sea water using a $0.2 \mu \mathrm{m}$ filter, the 'dissolved' fraction actually includes colloidal material and free viruses $(\leq 0.1 \mu \mathrm{m})$. The choice here of $5 \mu \mathrm{m}$ as the boundary between large and small phytoplankton, instead of the more usual picoplankton $(<2 \mu \mathrm{m})$ and nanoplankton ( 2 to $20 \mu \mathrm{m}$ ), is because the present paper refers to trophic interactions and mesozooplankton generally do not efficiently graze particles $<5 \mu \mathrm{m}$ (e.g. Fortier et al. 1994). In addition, phytoplankton cells as small as $5 \mu \mathrm{m}$ can aggregate upon collision and thus sink out of the euphotic zone, as shown experimentally by Kiorboe et al. (1990) for 3 small diatoms, i.e. Phaeodactylum tricornutum $(6.0 \mu \mathrm{m}$ equivalent spherical diameter. ESD), Thalassiosira pseudonana. (4.7 $\mu \mathrm{m}$ ESD), and Skeletonema costatum (5.5 $\mu \mathrm{m}$ ESD). Given that the size spectrum of photosynthetic products is continuous, from the largest phytoplanktor to the smallest exuded organic molecules, the boundaries between large and small phytoplankton and DOC are somewhat arbitrary. The same is true for the turnover times of biogenic carbon, whose spectrum is continuous 
Fig. 1 summarizes the major flows of biogenic carbon in the euphotic zone of oceans, from the 3 size classes of primary production to the 3 carbon pools Note that flows (defined here as exchanges of biogenic carbon among trophic compartments of the food web) are not the same as the 3 fluxes defined above (i.e. euphotic-zone remineralization, food-web transfer, and sinking to depth of organic particles). Following Legendre (1996), the Fig 1 shows that oxidation of DOC by heterotrophic bacteria and respiration by microzooplankton generally correspond to short-lived organic carbon, because these flows rapidly convert organic carbon back to $\mathrm{CO}_{2}$. The flows of organic carbon into the long-lived pool are mediated by mesozooplankton (mainly copepods) grazing on large cells, organic aggregates (e.g. marine snow) and microzooplankton, and by microphagous macrozooplankton (e.g. salps, doliolids, appendicularians, and pteropods; these organisms can also feed on large particles) feeding on small particles and aggregates. Part of this carbon reaches large metazoans such as fish and marine mammals. Finally, sedimentation to deep waters of rapidly sinking aggregated algal cells and faecal pellets (mainly from microphagous macrozooplankton; see Fortier et al. 1994) may lead to the sequestration of biogenic carbon in deep ocean basins and, to a smaller extent, in sediments on continental shelves. As pointed out by Legendre \& Le Fèvre (1991), longlived (refractory) DOC can effectively sequester biogenic carbon without it necessarily being exported to depth.

\section{BIOGENIC CARBON PATHWAYS}

Legendre \& Rassoulzadegan (1995) proposed that, in the pelagic environment, there is a continuum of trophic pathways, from the herbivorous food chain, to the multivorous and microbial food webs and to the microbial loop. By definition, the microbial loop is an almost closed system (a truly closed system could only be transient) of heterotrophic bacteria and zooflagellate grazers, in which the latter release dissolved organic matter (DOM) used as substrate by the former (e.g. Hagström et al. 1988). In contrast, the microbial food web includes small phytoplankton (which account for most primary production in oligotrophic oceans), so that it can export biogenic carbon (Rassoulzadegan 1993). The present paper focuses on the fate of bio- genic carbon, and therefore considers an additional pathway, i.e. sinking of ungrazed phytoplankton. As illustrated in Fig 1, the flows of biogenic carbon can be reduced to 5 broad pathways, which are ordered along a continuum of decreasing export relative to primary production: (1) sinking of ungrazed phytoplankton, (2) herbivorous, (3) multivorous and (4) microbial food webs, and (5) the microbial loop. At one end of the continuum (1), there is sinking of ungrazed phytoplankton and, at the other (5), biogenic carbon is remineralized within the bacteria-microzooplankton loop. In (3), the multivorous food web, herbivorous and microbial trophic modes both play significant roles. The 2 other, intermediate pathways, (2) herbivorous and (4) microbial food webs, are dominated by herbivorous and microbial grazing, respectively. Within the context of the present paper, it is much easier to determine relationships among a small number of biogenic carbon pathways and food-web or hydrodynamic variables than for a large number of interconnected flows.

The flows of biogenic carbon within ecosystems are largely determined by the size structure of primary producers and by grazing pressure. These 2 factors are controlled by the degree of segregation (or, conversely, matching = 1 - segregation) among trophic components. The concept of segregation was introduced by Margalef (e.g. 1978, 1985) who stressed that, when trophic components are segregated 

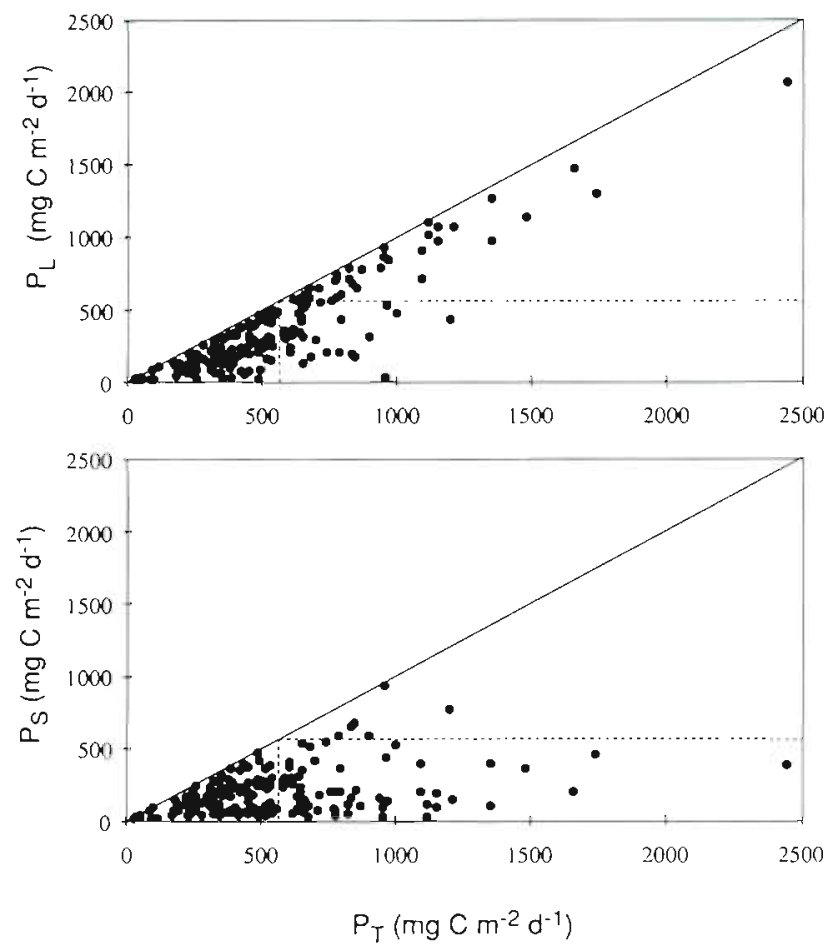

Fig. 2. Size-fractionated phytoplankton production $(P)$ from various marine environments. Values in the large $\left(P_{\mathrm{L}}\right)$ and small $\left(P_{S}\right)$ size fractions are plotted as functions of total primary production $P_{\mathrm{T}}=P_{\mathrm{L}}+P_{\mathrm{S}}$. The main diagonal represents $P_{\mathrm{T}}$ and the dashed lines provide visual references corresponding to $550 \mathrm{mg} \mathrm{C} \mathrm{m}^{-2} \mathrm{~d}^{-1}$ For $P_{\mathrm{T}}$ higher than the latter reference value (68 data points), $56 \%(38 / 68)$ of the $P_{L}$ points and $9 \%(6 / 68)$ of the $P_{\mathrm{S}}$ points are located above the horizontal line (i.e. $>550 \mathrm{mg} \mathrm{C} \mathrm{m}^{-2} \mathrm{~d}^{-1}$ ). Total of 195 data points from 13 published papers (see Table 1) (i.e. exhibit low spatio-temporal covariance), exchanges of energy and materials within ecosystems are reduced. This concept was borrowed from colloid chemistry, where it is known that reactivity decreases upon compartmentation of the space and that the process can be reaccelerated by mixing (Smoluchovski 1918, Margalef 1993). Hence, high primary production reflects low spatio-temporal segregation between the 2 factors that govern phytoplankton, i.e. irradiance and nutrients. Fig. 2 shows that, in oceans, most primary production above ca $550 \mathrm{mg} \mathrm{C} \mathrm{m}^{2} \mathrm{~d}^{1}$ is due to large phytoplankton (data taken from sources listed in Table 1). Hence, there exists an overall positive relationship between total phytoplankton production $\left(P_{\mathrm{T}}\right)$ and that of large phytoplankton $\left(P_{\mathrm{L}}\right)$. It follows that low segregation between irradiance and nutrients generally enhances $P_{\mathrm{L}}$. Concerning the second factor involved in the control of ecosystem flows, high grazing pressure reflects low spatio-temporal segregation between phytoplankton and their zooplankton grazers. To summarize, the flows of biogenic carbon in marine pelagic ecosystems are mainly governed by 2 food-web characteristics, i.e. the size structure of primary production and the segregation between primary production and grazing.

In the 2 extreme biogenic carbon pathways identified in Fig. 1, trophic components are highly segregated in space and time. At one end of the spectrum (1), massive sinking of ungrazed phytoplankton occurs when large cells are not grazed by mesozooplankton during the bloom, i.e. when there is strong segregation between the production of large phytoplankton and their grazing by zooplankton. At the other end of the spectrum (5), the microbial loop occurs when phyto-

Table 1 Characteristics of total and size-fractionated phytoplankton production data plotted in Fig. 2. Threshold between the 2 size fractions $(\mu \mathrm{m})$; daily $(D)$ or hourly $(H)$ values, the latter multiplied by 10 in Fig. 2 to obtain estimates of daily primary production; ecological situation; number of data points; source of data

\begin{tabular}{|c|c|c|c|c|}
\hline Threshold & $\mathrm{D} / \mathrm{H}$ & Ecological situatıon & No. of data & Source \\
\hline 1 & $\mathrm{D}$ & North Atlantic $\left(39^{\circ}\right.$ to $\left.44^{\circ} \mathrm{N}\right)$ & 3 & Glover et al. (1986) \\
\hline 1 & $\mathrm{D}$ & Celtic Sea $\left(50^{\circ} \mathrm{N}\right)$ & 9 & Joint et al. (1986) \\
\hline 1 & $\mathrm{D}$ & North Atlantic $\left(47^{\circ}\right.$ to $\left.60^{\circ} \mathrm{N}\right)$ & 28 & Joint et al. (1993) \\
\hline 2 & $\mathrm{D}$ & Indian Ocean $\left(5^{\circ}\right.$ to $\left.15^{\circ} \mathrm{N}\right)$ & 1 & Gomes et al. (1992) \\
\hline 2 & $D$ & Indian Ocean $\left(18^{\circ}\right.$ to $\left.23^{\circ} \mathrm{N}\right)$ & 9 & Jochem et al. (1993) \\
\hline 2 & $\mathrm{D}$ & Tropical and subtropical Atlantic & 15 & Jochem \& Zeitzschel (1.993) \\
\hline 2.5 & $D$ & Black Sea $\left(43^{\circ} \mathrm{N}\right)$ & 3 & Krupatkina et al. (1991) \\
\hline 3 & $\mathrm{D}$ & Baltic Sea $\left(56^{\circ} N\right)$ & 12 & Kuparinen $(1987)$ \\
\hline 3 & $\mathrm{H}$ & North Atlantic $\left(35^{\circ}\right.$ to $\left.44^{\circ} \mathrm{N}\right)$ & 5 & Glover et al. (1985) \\
\hline 3 & $\mathrm{H}$ & Mediterranean Sea & 4 & Berman et al. (1984) \\
\hline 5 & $\mathrm{D}$ & North Atlantic $\left(39^{\circ}\right.$ to $\left.44^{\circ} \mathrm{N}\right)$ & 3 & Glover et al. (1986) \\
\hline 5 & $\mathrm{D}$ & Celtic Sea $\left(50^{\circ} N\right)$ & 10 & Joint et al. $(1986)$ \\
\hline 5 & $\mathrm{D}$ & North Atlantic and Arctic $\left(75^{\circ} \mathrm{N}\right)$ & 11 & Legendre et al. (1993) \\
\hline 5 & $\mathrm{D}$ & Coastal North Pacific $\left(38^{\circ} \mathrm{N}\right)$ & 40 & Cole et al. (1986) \\
\hline 5 & $\mathrm{D}$ & North Atlantic $\left(47^{\circ}\right.$ to $\left.60^{\circ} \mathrm{N}\right)$ & 28 & Joint et al. (1993) \\
\hline 5 & $\mathrm{H}$ & Coastal Norway $\left(60^{\circ} \mathrm{N}\right)$ & 14 & Erga \& Heimdal (1984) \\
\hline
\end{tabular}


plankton production is very low or even nil, because of severe irradiance or nutrient limitation, i.e. strong segregation between irradiance and nutrients. The 2 intermediate pathways exhibit intermediate levels of segregation between trophic components. (2) In the herbivorous food web, there is strong grazing pressure exerted on large phytoplankton by mesozooplankton. This is often the case near the end of a bloom, when the time lag between enhanced production of large cells and their grazing is relatively short. (4) In the microbial food web, the biomass of small phytoplankton is controlled by microzooplankton. This requires contact rates between phytoplankton and microzooplankton to be high. Finally, (3) in the multivorous food web, primary production is shared by large and small phytoplankton. Active grazing by large and small zooplankton indicates that there is little segregation between primary producers and their grazers

In the next section, the above ideas will be expressed as equations. The size structure of primary production will then be quantified as the production of large to total phytoplankton $\left(P_{\mathrm{L}} / P_{\mathrm{T}}\right)$, whereas the spatio-temporal coupling between primary production and grazing will be represented by the matching $(M$ i segregation = $1-M$ ) between these 2 rate processes.

\section{FOOD-WEB CONTROL OF BIOGENIC CARBON PATHWAYS}

The 3 main fluxes of net (vs gross) phytoplankton production $(P)$ are: (1) remineralization within the euphotic zone ( $R$, i.e. respiration) and export out of the euphotic zone $(E)$ by (2) food-web transfer $(F)$ and (3) downward POC flux $(D)$, so that $E=F+D$. Part of the carbon exported from the euphotic zone to the food web is rapidly egested, excreted or respired, so that only a small fraction of $F$ contributes to the production of herbivores and other trophic compartments (secondary production is generally defined as a change in biomass per unit time). In order to apply the model locally, it is assumed that, over appropriate time and space scales, all phytoplankton production is respired or exported and horizontal advection is negligible relative to the other fluxes. The above terms are related as follows

$$
P=R+E=R+F+D
$$

All terms in Eq. (1) have units of mass per unit volume (or area) and per unit time. Each term on the righthand side may result from the combination of several food-web flows. For example, carbon respired within the euphotic zone which is fixed again by phytoplankton and ultimately transferred to the food web belongs to $F$ and not $R$.
Eq. (1) is valid not only for the total phytoplankton assemblage $(T)$ but also for size fractions, i.e. large (L) and small (S) phytoplankton. The present development does not consider the third size class of primary production identified above (DOC; see Fig. 1). This is because the production of DOC by phytoplankton is not routinely determined at sea and little is known concerning the overall flows and fluxes of this component in the marine environment. However, it is generally agreed that, except under unusual circumstances, the production of DOC does not exceed ca $10 \%$ of total gross primary production (e.g. Sharp 1984, Wood et al. 1992). Hence, in Eq. (2), $P_{\mathrm{T}}$ does not include the exudation of DOC by phytoplankton. Each term of Eq. (1) can be algebraically partitioned between the large and small size fractions:

$$
\begin{aligned}
& P_{\mathrm{T}}=P_{\mathrm{L}}+P_{\mathrm{S}} \\
& E_{\mathrm{T}}=E_{\mathrm{L}}+E_{\mathrm{S}} \\
& R_{\mathrm{T}}=R_{\mathrm{L}}+R_{\mathrm{S}} \\
& F_{\mathrm{T}}=F_{\mathrm{L}}+F_{\mathrm{S}} \\
& D_{\mathrm{T}}=D_{\mathrm{L}}+D_{\mathrm{S}}
\end{aligned}
$$

By using Eqs. (2) to (6), Eq. (1) is rewritten for the total phytoplankton assemblage and the 2 size fractions:

$$
\begin{aligned}
& P_{\mathrm{T}}=R_{\mathrm{T}}+E_{\mathrm{T}}=R_{\mathrm{T}}+F_{\mathrm{T}}+D_{\mathrm{T}} \\
& P_{\mathrm{L}}=R_{\mathrm{L}}+E_{\mathrm{L}}=R_{\mathrm{L}}+F_{\mathrm{L}}+D_{\mathrm{L}} \\
& P_{\mathrm{S}}=R_{\mathrm{S}}+E_{\mathrm{S}}=R_{\mathrm{S}}+F_{\mathrm{S}}+D_{\mathrm{S}}
\end{aligned}
$$

The model will first be developed using the following 2 simplifying assumptions: large phytoplankton are mostly not remineralized in the euphotic zone and small phytoplankton generally do not sink out of the euphotic zone. These 2 assumptions, which are discussed later (Eqs. 26 to 31), can be written as:

$$
\begin{aligned}
& R_{\mathrm{L}} \ll F_{\mathrm{L}}+D_{\mathrm{L}} \\
& D_{\mathrm{S}} \ll R_{\mathrm{S}}+F_{\mathrm{S}}
\end{aligned}
$$

Combining Eqs. (8) \& (10) and Eqs. (9) \& (11), respectively, gives:

$$
\begin{aligned}
& P_{\mathrm{L}}=F_{\mathrm{L}}+D_{\mathrm{L}} \\
& P_{\mathrm{S}}=R_{\mathrm{S}}+F_{\mathrm{S}}
\end{aligned}
$$

Additional assumptions are that the proportions of primary production channelled into $F_{\mathrm{L}}$ and $F_{\mathrm{S}}$ are direct functions of the degree of matching $(M)$ between primary production and overall grazing. $M$ is a dimensionless number, whose values range from 0 to 1 Linear equations are used here given that, as mentioned above, there is a linear relationship between primary production and food-web export (e.g. Iverson 1990). Hence

$$
\begin{aligned}
& F_{\mathrm{L}} / P_{\mathrm{L}}=f(M)=k_{\mathrm{L}} M, \text { thus } F_{\mathrm{L}}=P_{\mathrm{L}} k_{\mathrm{L}} M \\
& F_{\mathrm{S}} / P_{\mathrm{S}}=f(M)=k_{\mathrm{S}} M, \text { thus } F_{\mathrm{S}}=P_{\mathrm{S}} k_{\mathrm{S}} M
\end{aligned}
$$

where $k_{\mathrm{L}}$ and $k_{\mathrm{S}}$ are constants. Because $F_{\mathrm{L}} / P_{\mathrm{L}} \leq 1$, $F_{\mathrm{S}} / P_{\mathrm{S}} \leq 1$, and $M \leq 1$, it follows that $k_{\mathrm{L}} \leq 1$ and $k_{\mathrm{S}} \leq 1$. 
Given Eq. (12), Eq. (6) is rewritten as:

$$
D_{\mathrm{T}}-D_{\mathrm{S}}=P_{\mathrm{L}}-F_{\mathrm{L}}
$$

It will be shown below (Table 2) that, in situations where primary production is dominated by small phytoplankton $\left(P_{L} / F_{\Gamma} \leq 0.35\right)$ and where, as a consequence, $D_{s}$ is likely of significance, the total downward POC flux is very small $\left(D_{\top} / P_{\mathrm{T}} \leq 0.1\right)$. Hence, it is assumed that, when $D_{\top} \Rightarrow 0, D_{\mathrm{S}}$ is small so that the above equation is simplified as follows:

$$
D_{\mathrm{T}}=P_{\mathrm{L}}-F_{\mathrm{L}}
$$

Combining Eqs. (14) \& (16) gives:

$$
D_{\top}=P_{\mathrm{L}}-P_{\mathrm{L}} k_{\mathrm{L}} M=\left(1-k_{\mathrm{L}} M\right) P_{\mathrm{L}}
$$

In order to express $D_{\mathrm{T}}$ as a function of the size structure of primary production $\left(P_{\mathrm{L}} / P_{\mathrm{T}}\right)$. Eq. (17) is divided by $P_{\mathrm{T}}$

$$
D_{\mathrm{T}} / P_{\mathrm{T}}=\left(1-k_{\mathrm{L}} M\right)\left(P_{\mathrm{L}} / P_{\mathrm{T}}\right)
$$

Similarly, given Eq. (13), Eq. (4) is rewritten as:

$$
R_{T}-R_{\mathrm{L}}=P_{5}-F_{\mathrm{S}}
$$

It will be shown below (Table 2) that, in situations where primary production is dominated by large phytoplankton $\left(P_{\mathrm{L}} / P_{\mathrm{T}} \geq 0.80\right)$ and where, as a consequence, $R_{\mathrm{L}}$ is likely of significance, total euphotic-zone remineralization is very small $\left(R_{\mathrm{T}} / P_{\mathrm{T}} \leq 0.3\right)$. Hence, it is assumed that, when $R_{\mathrm{T}} \geqslant 0, R_{\mathrm{L}}$ is small so that the above equation is simplified as follows:

$$
R_{\mathrm{T}}=P_{\mathrm{S}}-F_{\mathrm{S}}
$$

Combining Eqs. (15) \& (19) gives:

$$
R_{\mathrm{T}}=P_{\mathrm{S}}-P_{\mathrm{S}} k_{\mathrm{S}} M=\left(1-k_{\mathrm{S}} M\right) P_{\mathrm{S}}
$$

Which, after division by $P_{\mathrm{T}}$, becomes:

$$
R_{\mathrm{T}} / P_{\mathrm{T}}=\left(1-k_{\mathrm{S}} M\right)\left(P_{\mathrm{S}} / P_{\mathrm{T}}\right)
$$

Or, using Eq. (2):

$$
R_{\mathrm{T}} / P_{\mathrm{T}}=\left(1-k_{\mathrm{S}} M\right)\left(1-P_{\mathrm{L}} / P_{\mathrm{T}}\right)
$$

Eq. (7) provides the expression for $F_{\mathrm{T}} / P_{\mathrm{T}}$ :

$$
F_{\mathrm{T}} / P_{\mathrm{T}}=1-\left(R_{\mathrm{T}} / P_{\mathrm{T}}+D_{\mathrm{T}} / P_{\mathrm{T}}\right)
$$

Using Eqs. (18) \& (22), Eq. (23) is rewritten as a function of $M$ and $P_{\mathrm{L}} / P_{\mathrm{T}}$ :

$$
F_{\mathrm{T}} / P_{\mathrm{T}}=M\left[k_{\mathrm{S}}+\left(k_{\mathrm{L}}-k_{\mathrm{S}}\right)\left(P_{\mathrm{L}} / P_{\mathrm{T}}\right)\right]
$$

It must be noted that, because of Eq. (2), Eq. (24) can be rewritten as follows:

$$
F_{\mathrm{T}} / \mathrm{P}_{\mathrm{T}}=M\left(k_{\mathrm{L}} P_{\mathrm{L}}+k_{\mathrm{S}} P_{\mathrm{S}}\right) / P_{\mathrm{T}}
$$

which is identical to the sum $F_{\mathrm{L}}+F_{\mathrm{S}}$ (Eqs. $\left.14 \& 15\right)=F_{\mathrm{T}}$ (Eq. 5), divided by $P_{\mathrm{T}}$.

The ratio of total export from the euphotic zone, through the combined mechanisms of food-web trans- fer and downward POC flux (Eq. 1), to total primary production is computed using Eq. (22):

$$
\begin{aligned}
& E_{\mathrm{T}} / P_{\mathrm{T}}=F_{\mathrm{T}} / P_{\mathrm{T}}+D_{\mathrm{T}} / P_{\mathrm{T}}=1-R_{\mathrm{T}} / P_{\mathrm{T}} \\
& E_{\mathrm{T}} / P_{\mathrm{T}}=1-\left(1-k_{\mathrm{S}} M\right)\left(1-P_{\mathrm{L}} / P_{\mathrm{T}}\right)
\end{aligned}
$$

Eqs. (18), (22), (24) \& (25) link $D_{\mathrm{T}} / P_{\mathrm{T}}, R_{\mathrm{T}} / P_{\mathrm{T}}, F_{\mathrm{T}} / P_{\mathrm{T}}$, and $E_{\mathrm{T}} / P_{\mathrm{T}}$, respectively, to the 2 food-web variables identified in the previous section $\left(P_{\mathrm{L}} / P_{\mathrm{T}}\right.$ and $\left.M\right)$, using 2 constants ( $k_{\mathrm{L}}$ and $k_{\mathrm{S}}$ ).

Tremblay et al. (in press) have shown that there is a linear relationship, at sea, between $P_{L} / P_{0}$ and the $f$-ratio, i.e. the ratio of nitrate uptake by phytoplankton to the total uptake of nitrogenous nutrients (Eppley \& Peterson 1979). It follows that $P_{L} / P_{\uparrow}$ provides a connection between the above equations and the uptake of nitrogenous nutrients in oceans.

The above 2 simplifying assumptions (Eqs. 10 \& 11) may not be realistic under all circumstances. Concerning the assumption that $R_{\mathrm{L}} \ll\left(F_{\mathrm{L}}+D_{\mathrm{L}}\right)$ (Eq. 10), it is known that some heterotrophic dinoflagellates can eat diatoms as large as, or even larger than themselves (e.g Hansen 1991, Lessard 1991). This, together with sloppy feeding by mesozooplankton (e.g. Roy et al. 1989), could lead to significant remineralization of large-size primary production within the euphotic zone. In situations with significantly high $R_{\mathrm{L}}$ (combined with low $D_{\mathrm{Si}}$ Eq. 11), it can be shown that $D_{\mathrm{T}} / P_{\mathrm{T}}$ (Eq. 18) would be diminished by $R_{\mathrm{L}} / P_{\mathrm{T}}$ and that $R_{\mathrm{T}} / P_{\mathrm{T}}$ (Eq. 21) would be augmented by the same quantity:

$$
\begin{aligned}
& D_{\mathrm{T}} / P_{\mathrm{T}}=\left(1-k_{\mathrm{L}} M\right)\left(P_{\mathrm{L}} / P_{\mathrm{T}}\right)-R_{\mathrm{L}} / P_{\mathrm{T}} \\
& R_{\mathrm{T}} / P_{\mathrm{T}}=\left(1-k_{\mathrm{S}} M\right)\left(1-P_{\mathrm{L}} / P_{\mathrm{T}}\right)+R_{\mathrm{L}} / P_{\Upsilon}
\end{aligned}
$$

Because $F_{\mathrm{T}} / P_{\mathrm{T}}$ would be the same as in Eqs. (23) \& (24), total export (Eq. 25) would be diminished by $R_{\mathrm{L}} / P_{\mathrm{T}}$ :

$$
E_{\mathrm{T}} / \mathrm{P}_{\top}=1-\left(1-k_{\mathrm{S}} M\right)\left(1-P_{\mathrm{L}} / P_{\mathrm{T}}\right)-R_{\mathrm{L}} / P_{\mathrm{T}}
$$

Concerning the assumption that $D_{\mathrm{S}} \leqslant\left(R_{\mathrm{S}}+F_{\mathrm{S}}\right)$ (Eq. 11), there are cases where microphagous macrozooplankton package significant amounts of small phytoplankton into large, fast-sinking faecal pellets (see above and Fig. 1). In situations with significantly high $D_{\mathrm{S}}$ (combined with low $R_{\mathrm{L}}$ Eq. 10), it can be shown that $D_{\mathrm{T}} / P_{\mathrm{T}}$ (Eq. 18) would be augmented by $D_{\mathrm{S}} / P_{\mathrm{T}}$ and that $R_{\mathrm{T}} / P_{\mathrm{T}}$ (Eq. 21) would be diminished by the same quantity

$$
\begin{aligned}
& D_{\mathrm{T}} / P_{\mathrm{T}}=\left(1-k_{\mathrm{L}} M\right)\left(P_{\mathrm{L}} / P_{\mathrm{T}}\right)+D_{\mathrm{S}} / P_{\mathrm{T}} \\
& R_{\mathrm{T}} / \mathrm{P}_{\mathrm{T}}=\left(1-k_{\mathrm{S}} M\right)\left(1-P_{\mathrm{L}} / P_{\mathrm{T}}\right)-D_{\mathrm{S}} / P_{\mathrm{T}}
\end{aligned}
$$

Because $F_{\mathrm{T}} / P_{\mathrm{T}}$ would be the same as in Eqs. (23) \& (24), total export (Eq. 25) would be augmented by $D_{\mathrm{S}} / P_{\mathrm{T}}$

$$
E_{\mathrm{T}} / \mathrm{P}_{\mathrm{T}}=1-\left(1-k_{\mathrm{S}} M\right)\left(1-P_{\mathrm{L}} / P_{\mathrm{T}}\right)+D_{\mathrm{S}} / P_{\mathrm{T}}
$$

The other 2 assumptions (Eqs. 14 \& 15) will be discussed in the next section.

Finally, using different values of $M$ for the large- and small-size fractions $\left(M_{\mathrm{L}}\right.$ and $\left.M_{\mathrm{S}}\right)$ would not change the 
above results. With 2 values of $M$, Eqs. (14) \& (15) are rewritten:

$$
\begin{aligned}
& F_{L}=P_{L} c_{L} M_{L} \\
& F_{S}=P_{S} c_{S} M_{S}
\end{aligned}
$$

However, values of coefficients $c_{L}$ and $c_{S}$ are not the same as $k_{\mathrm{L}}$ and $k_{\mathrm{S}}$ :

$$
\begin{aligned}
& F_{\mathrm{L}}=P_{\mathrm{L}} k_{\mathrm{L}} M=P_{\mathrm{L}} c_{\mathrm{L}} M_{\mathrm{L}} \\
& F_{\mathrm{S}}=P_{\mathrm{S}} k_{\mathrm{S}} M=P_{S} c_{S} M_{\mathrm{S}}
\end{aligned}
$$

so that:

$$
\begin{aligned}
& k_{\mathrm{L}} M=c_{\mathrm{L}} M_{\mathrm{L}} \\
& k_{S} M=c_{S} M_{\mathrm{S}}
\end{aligned}
$$

Developing Eqs. (32) \& (33) gives:

$$
\begin{aligned}
& D_{\top} / P_{\top}=\left(1-C_{\mathrm{L}} M_{\mathrm{L}}\right)\left(P_{\mathrm{L}} / P_{\mathrm{T}}\right) \\
& R_{\mathrm{T}} / P_{\top}=\left(1-c_{\mathrm{S}} M_{\mathrm{S}}\right)\left(1-P_{\mathrm{L}} / P_{\top}\right)
\end{aligned}
$$

Because of relations given by Eqs. (34) \& (35) between $k_{\mathrm{L}}$ and $c_{\mathrm{L}}$ and $k_{\mathrm{S}}$ and $c_{\mathrm{S}}$, respectively, Eq. (36) is the same as Eq. (18) and Eq. (37) the same as Eq. (22). Hence, using $2 \mathrm{M}$ values would not change the model, because of corresponding changes in the 2 constants. The model is thus based on a single $M$ value.

\section{FITTING OF MODEL PARAMETERS TO DATA}

Table 2 shows values of $P_{\mathrm{L}} / P_{\mathrm{T}}, R_{\mathrm{T}} / P_{\mathrm{T}}, F_{\top} / P_{\mathrm{T}}, D_{\mathrm{T}} / P_{\mathrm{T}}$, and $E_{T} / P_{T}$ for the 5 biogenic carbon pathways identified above, based on data from the literature. Values of $M$ are derived from the authors' experience and are thus open to discussion (details concerning the derivation of $M$ values are provided in the next section).

(1) Massive sinking of phytoplankton, following ungrazed blooms of large cells, has been reported in a number of papers (cited in Legendre 1990). Under such circumstances, primary production is strongly dominated by large cells (for simplicity, $P_{\mathrm{L}} / P_{\mathrm{T}}=1.0$, even if there is always some production by small phytoplankton; see Fig. 2) and most of it sinks to depth $\left(D_{\mathrm{\top}} / P_{\mathrm{\top}}=1.0\right)$
(2) Herbivorous grazing often occurs at times of blooms. In the Gulf of St. Lawrence (eastern Canada; Rivkin et al. 1996), during the spring phytoplankton bloom, the $>5 \mu \mathrm{m}$ size fraction accounted for 0.49 to 1.00 of the primary production (hence $P_{L} / P_{T}=0.8$ in Table 2). Dividing the $f$-ratio (new/total phytoplankton production: $P_{\mathbb{N}} / P_{T}$ ) by the ratio of $P_{N}$ to the downwald POC flux (POC was then mostly algal material, so that $P_{N} / \mathrm{POC}=P_{N} / D_{\mathrm{T}}$, assuming no allochthonous input of POC) provides values for $D_{\top} / P_{T}=0.02$ to 0.09 (hence $D_{\mathrm{T}} / P_{\mathrm{T}}=0.1$ in Table 2 ). The value $R_{\mathrm{T}} / P_{\mathrm{T}}=0.3 \mathrm{w}$ as chosen as intermediate between those for the sinking and multivorous pathways. By difference, $F_{\mathrm{T}} / P_{1}=1-$ $\left(D_{\mathrm{T}} / P_{\mathrm{T}}+R_{\mathrm{T}} / P_{\mathrm{T}}\right)=0.6$

(3) The paper of Rivkin et al. (1996) also provides values for the multivorous food web (post-bloom conditions): $P_{\mathrm{L}} / P_{\mathrm{T}}=0.09$ to 0.43 and, given that most of the sinking POC flux was then of non-algal origin (their Fig. 2), the same calculation as above (there for $D_{\mathrm{T}} / P_{\mathrm{T}}$ ) gives $F_{\mathrm{T}} / P_{\mathrm{T}}<0.33$ to 0.60 . Additional estimates can be found in Moloney et al. (1991), who modelled pelagic ecosystems off western South Africa. Their results for phytoplankton combine sinking of ungrazed cells together with 'senescence' (and lysis; according to their Table 1, the senescence rate increases with decreasing cell size and increasing temperature). Two of the studied systems correspond to the multivorous food web, i.e the Agulhas Bank and the Benguela Upwelling. According to their Fig. 21, $P_{L} / P_{\mathrm{T}}$ (gross) $=$ 0.13 to 0.28 (proportion of total gross phytoplankton production in the $>5 \mu \mathrm{m}$ size fraction), $D_{\mathrm{T}} / P_{\mathrm{T}}<0.13$ to 0.18 (proportion of net primary production, including exuded DOC, channelled into phytoplankton sinking and senescence), $F_{\mathrm{T}} / P_{\mathrm{T}}=0.30$ to 0.31 (proportion of net primary production and exuded $D O C$ exported as sinking faecal pellets), $E_{\mathrm{T}} / P_{\mathrm{T}}=D_{\mathrm{T}} / P_{\mathrm{T}}+F_{\mathrm{T}} / P_{\mathrm{T}}<0.42$ to 0.48 , and $R_{\top} / P_{\top}=1-E_{\top} / P_{\top}>0.52$ to 0.58 . Finally, Legendre \& Rassoulzadegan (1995) used the subarctic Pacific Ocean as an example for the multivorous food

\begin{tabular}{|c|c|c|c|c|c|c|}
\hline Biogenic carbon pathway & $P_{\mathrm{L}} / P_{\mathrm{T}}$ & M & $R_{\mathrm{T}} / P_{\mathrm{T}}$ & $F_{\mathrm{T}} / P_{\top}$ & $D_{\mathrm{T}} / P_{\mathrm{T}}$ & $E_{\mathrm{T}} / P_{\mathrm{T}}$ \\
\hline (1) Sinking of ungrazed cells & 1.00 & 0.00 & 0.0 & 0.0 & 1.0 & 1.0 \\
\hline (2) Herbivorous food web & 0.80 & 0.55 & 0.3 & 0.6 & 0.1 & 0.7 \\
\hline (3) Multivorous food web & 0.35 & 0.65 & 0.6 & 0.3 & 0.1 & 0.4 \\
\hline (4) Microbial food web & 0.10 & 0.25 or 0.75 & 0.8 & 0.2 & 0.0 & 0.2 \\
\hline (5) Microbial loop & 0.00 & 0.00 or 1.00 & 1.0 & 0.0 & 0.0 & 0.0 \\
\hline
\end{tabular}
web. Miller et al. (1991) published estimates for grazing on phytoplankton by micro-and mesozooplankton, based on several cruises in the area. Part of the carbon

Table 2. Values of ecosystem characteristics for the 5 biogenic carbon pathways identified in the text, based on data from the literature (except for $M$ ). P: phytoplankton production; $M$ : degree of matching between primary production and grazing: $R$ : remineralization within the euphotic zone; $F$ : food-web transfer; $D$ : downward POC flux; $E$ : total export from the euphotic zone $(E=F+D)_{i} T:$ total phytoplankton assemblage; L: large size fraction 
grazed by small zooplankton is passed on to large zooplankton, so that micrograzing provides maximum estimates for $R_{\mathrm{T}}$, whereas large zooplankton can graze both large algae and microzooplankton, so that macrograzing on phytoplankton provides minimum estimates for $F_{\mathrm{T}}$. In Table 3 of Miller et al. (1991), values for the ratio of micro- to total grazing range from 0.70 to 0.93 , hence $R_{\mathrm{T}} /\left(R_{\mathrm{T}}+F_{\mathrm{T}}\right) \leq 0.70$ and $F_{\mathrm{T}} /\left(R_{\mathrm{T}}+F_{\mathrm{T}}\right) \geq 0.30$ These are consistent with values of $R_{\Upsilon} / P_{\mathrm{T}}$ and $F_{\mathrm{T}} / P_{\mathrm{T}}$ in our Table 2, i.e. $R_{\mathrm{T}} /\left(R_{\mathrm{T}}+F_{\mathrm{T}}\right)=0.67$ and $F_{\mathrm{T}} /\left(R_{\mathrm{T}}+F_{\mathrm{T}}\right)=$ 0.33 .

(4) Estimates for the microbial food web can be derived from model results of Moloney et al. (1991) for oceanic waters: $P_{\mathrm{L}} / P_{\mathrm{T}}=0.03$ and $D_{\mathrm{T}} / P_{\mathrm{T}} \approx 0$ (because of dominance by small phytoplankton and high temperature, sinking is very low and senescence is very high). Proportions of net primary production (including exuded DOC) channelled into phytoplankton senescence and exported as sinking faecal pellets are 0.27 and 0.17 , respectively. Assuming that ca $10 \%$ of the organic carbon from lysed phytoplankton is exported through the food web, $F_{\mathrm{T}} / P_{\mathrm{T}}=0.17+0.03=0.2$, hence $R_{\mathrm{T}} / P_{\mathrm{T}}=0.8$. Legendre \& Rassoulzadegan (1995) used a study of Lancelot et al. (1993) on the ice-edge water column of the northwestern Weddell Sea to exemplify the microbial food web. In this system, phytoplankton 2 to $10 \mu \mathrm{m}$ account for $>80 \%$ of the autotrophic carbon biomass (their Fig. 3.3c). The model of Lancelot et al. (1993) provides the following estimates (their Table 6.II) for the marginal ice zone (MIZ) and the adjacent permanently open ocean zone (POOZ): $F_{\mathrm{T}} / P_{\mathrm{T}}<0.34$ to 0.36 (proportion of net primary production available for grazing by large zooplankton), hence $R_{\mathrm{T}} / P_{\mathrm{T}}>0.64$ to 0.66 . In oceans, the microbial food web occurs under 2 drastically different types of conditions, i.e. well-stratified surface layer (e.g. oligotrophic tropical waters) or deeply mixed water column (e.g. winter at mid-latitudes), hence $M=0.75$ or 0.25 .

(5) For the microbial loop, values in Table 2 correspond to the extreme case of a closed remineralizing system of bacteria and microzooplankton. In a truly closed loop, there would be almost no autotrophic production $\left(P_{\mathrm{T}}=0\right)$, so that $P_{\mathrm{L}} / P_{\mathrm{T}}=P_{\mathrm{S}} / \mathrm{P}_{\mathrm{T}}=F_{\mathrm{T}} / P_{\mathrm{T}}=D_{\mathrm{T}} / P_{\mathrm{T}}=$ $E_{\mathrm{T}} / P_{\mathrm{T}}=0$. The microbial loop can be seen as the limit case of the microbial food web (previous paragraph), hence $M=1.00$ or 0.00

Values of parameters $k_{L}$ and $k_{S}$ were computed by least-squares linear regression, using Eq. (24) and values in Table 2:

$$
\left(F_{\mathrm{T}} / P_{\mathrm{T}}\right) / M=k_{\mathrm{S}}+\left(k_{\mathrm{L}}-k_{\mathrm{S}}\right)\left(P_{\mathrm{L}} / P_{\mathrm{T}}\right)
$$

Table 2 provides 7 pairs of values for $\left(F_{\mathrm{T}} / P_{\mathrm{T}}\right) / M$ and $P_{\mathrm{L}} / P_{\mathrm{T}}$. In the 2 cases where $F_{\mathrm{T}} / P_{\mathrm{T}}$ and $M$ are both equal to zero, it was decided that $\left(F_{\mathrm{T}} / P_{\mathrm{T}}\right) / M=1$. The resulting values are $k_{\mathrm{L}}=1.0$ and $k_{\mathrm{S}}=0.4$

Table 3 shows estimates of $R_{\mathrm{T}} / P_{\mathrm{T}}, F_{\mathrm{T}} / P_{\mathrm{T}}, D_{\mathrm{T}} / P_{\mathrm{T}}$, and $E_{\top} / P_{T}$ for the 5 biogenic carbon pathways, computed using Eqs. (18), (22), (24) \& (25) and values of $P_{\mathrm{L}} / P_{\mathrm{T}}$ and $M$ from Table 2 . The 21 values for $R_{\mathrm{T}} / P_{\mathrm{T}}, F_{\mathrm{T}} / P_{\mathrm{T}}$ and $D_{\mathrm{T}} / P_{\mathrm{T}}$ account for $\mathrm{r}^{2}=0.83$ of the variance of corresponding values in Table $2(r=0.91, p<0.001)$. The high value of constant $k_{\mathrm{L}}$ (1.0) suggests that, when phytoplankton production is dominated by the large size fraction $\left(P_{L}\right)$, food-web transfer $\left(F_{L}\right.$ i mostly through herbivorous grazing) may be strongly influenced by the degree of matching $(M)$ between primary production and grazing (Eq. 14). In contrast, the relatively low value of constant $k_{\mathrm{S}}(0.4)$ suggests that, when the small size fraction is dominant $\left(P_{\mathrm{S}}\right)$, grazing on small phytoplankton $\left(F_{\mathrm{S}}\right)$ is not much influenced by $M$ (Eq. 15).

It is possible to increase the the fit of model to observed data by increasing the number of forecasting variables. For example, Eqs. (26) \& (27) could be used instead of Eqs. (18) \& (22), in order to include in the model remineralization of large-sized primary production within the euphotic zone $\left(R_{\mathrm{L}}\right)$. This should be especially significant for biogenic carbon pathways 2 and 3 , where mesozooplankton grazers play a major role. Exact values for $R_{\mathrm{L}} / P_{\mathrm{T}}$ are not known, since part of the carbon released as DOC by grazing is ultimately exported after being taken up by bacteria. Given that ingestion and digestion of phytoplankton can release as

Table 3. Values of ecosystem characteristics for the 5 biogenic carbon pathways identified in Table 2, computed here using Eqs. (18), (22), (24) \& (25), the values of $P_{\mathrm{L}} / P_{\mathrm{T}}$ and $M$ from Table 2 , and constants $k_{\mathrm{L}}=1.0$ and $k_{\mathrm{S}}=0.4$. Coefticient of determination $\mathrm{r}^{2}=0.83$ between the 2 sets of $21 R_{\mathrm{T}} / P_{\mathrm{T}}, F_{\mathrm{T}} / P_{\mathrm{T}}$ and $D_{\mathrm{T}} / P_{\mathrm{T}}$ values in Tables $2 \& 3$. Abbreviations as in Table 2

\begin{tabular}{|lcccccc|}
\hline Biogenic carbon pathway & $P_{\mathrm{L}} / P_{\mathrm{T}}$ & $M$ & $R_{\mathrm{T}} / P_{\mathrm{T}}$ & $F_{\mathrm{T}} / P_{\mathrm{T}}$ & $D_{\mathrm{T}} / P_{\mathrm{T}}$ & $E_{\mathrm{T}} / P_{\mathrm{T}}$ \\
\hline (1) Sinking of ungrazed cells & 1.00 & 0.00 & 0.00 & 0.00 & 1.00 & 1.00 \\
(2) Herbivorous food web & 0.80 & 0.55 & 0.16 & 0.48 & 0.36 & 0.84 \\
(3) Multivorous food web & 0.35 & 0.65 & 0.48 & 0.40 & 0.12 & 0.52 \\
(4) Microbial food web & 0.10 & 0.25 & 0.81 & 0.11 & 0.08 & 0.19 \\
Microbial food web & 0.10 & 0.75 & 0.63 & 0.34 & 0.03 & 0.37 \\
(5) Microbial loop & 0.00 & 0.00 & 1.00 & 0.00 & 0.00 & 0.00 \\
Microbial loop & 0.00 & 1.00 & 0.60 & 0.40 & 0.00 & 0.40 \\
\hline
\end{tabular}


Table 4. Values of ecosystem characteristics for the 5 biogenic carbon pathways, computed here using Eqs. (24), (26) \& (27), the values of $P_{\mathrm{L}} / P_{\mathrm{T}}$ and $M$ from Table 2 , the values of $R_{\mathrm{L}} / P_{\mathrm{T}}$ defined in the text, and constants $k_{\mathrm{L}}=1.0$ and $k_{\mathrm{s}}=0.4$. Coefficient of determination $\mathrm{r}^{2}=0.86$ between the 2 sets of $21 R_{\mathrm{T}} / P_{\mathrm{T}}, F_{\mathrm{T}} / P_{\mathrm{T}}$, and $D_{\mathrm{T}} / P_{\mathrm{T}}$ values in Tables $2 \& 4$. Abbrevations as in Table 2

\begin{tabular}{|lcccccc|}
\hline Biogenic carbon pathway & $P_{\mathrm{L}} / P_{\mathrm{T}}$ & $M$ & $R_{\mathrm{L}} / P_{\mathrm{T}}$ & $R_{\mathrm{T}} / P_{\mathrm{T}}$ & $F_{\mathrm{T}} / P_{\mathrm{T}}$ & $D_{\top} / P_{\mathrm{T}}$ \\
\hline (1) Sinking of ungrazed cells & 1.00 & 0.00 & 0.00 & 0.00 & 0.00 & 1.00 \\
(2) Herbivorous food web & 0.80 & 0.55 & 0.20 & 0.36 & 0.48 & 0.16 \\
(3) Multivorous food web & 0.35 & 0.65 & 0.10 & 0.58 & 0.40 & 0.02 \\
(4) Microbial food web & 0.10 & 0.25 & 0.03 & 0.66 & 0.34 & 0.00 \\
Microbial food web & 0.10 & 0.75 & 0.03 & 0.84 & 0.11 & 0.05 \\
(5) Microbial loop & 0.00 & 0.00 & 0.00 & 0.60 & 0.40 & 0.00 \\
Microbial loop & 0.00 & 1.00 & 0.00 & 1.00 & 0.00 \\
\hline
\end{tabular}

Table 5. Values of ecosystem characteristics for the 5 biogenic carbon pathways, computed here as in Table 3 , after perturbation of $P_{\mathrm{L}} / P_{\mathrm{T}}$ and $M$ by $\pm 20 \%$. Coefficients of determination between the $21 R_{\mathrm{T}} / P_{\mathrm{T}}, F_{\mathrm{T}} / P_{\mathrm{T}}$, and $D_{\mathrm{T}} / P_{\mathrm{T}}$ values in Table 2 and each set of corresponding values in the present table: $\mathrm{r}^{2}=0.83\left(P_{\mathrm{L}} / P_{\mathrm{T}}-20 \%\right), 0.79\left(P_{\mathrm{L}} / P_{\mathrm{T}}+20 \%\right), 0.85(M-20 \%), 0.77(M+20 \%)$. Abbreviations as in Table 2

\begin{tabular}{|lccccc}
\hline Biogenic carbon pathway & $P_{\mathrm{L}} / P_{\mathrm{T}}$ & $M$ & $R_{\mathrm{T}} / P_{\mathrm{T}}$ & $F_{\mathrm{T}} / P_{\mathrm{T}}$ & $D_{\mathrm{T}} / P_{\mathrm{T}}$ \\
\hline $\pm 20 \%$ perturbation of $P_{\mathrm{L}} / P_{\mathrm{T}}$ & & & & & \\
(1) Sinking of ungrazed cells & $0.80-1.00$ & 0.00 & $0.20-0.00$ & $0.00-0.00$ & $0.80-1.00$ \\
(2) Herbivorous food web & $0.64-0.96$ & 0.55 & $0.28-0.03$ & $0.43-0.54$ & $0.29-0.43$ \\
(3) Multivorous food web & $0.28-0.42$ & 0.65 & $0.53-0.43$ & $0.37-0.42$ & $0.10-0.15$ \\
(4) Microbial food web & $0.08-0.12$ & 0.25 & $0.83-0.79$ & $0.11-0.12$ & $0.06-0.09$ \\
Microbial food web & $0.08-0.12$ & 0.75 & $0.64-0.62$ & $0.34-0.35$ & $0.02-0.03$ \\
(5) Microbial loop & $0.00-0.00$ & 0.00 & $1.00-1.00$ & $0.00-0.00$ & $0.00-0.00$ \\
Microbial loop & $0.00-0.00$ & 1.00 & $0.60-0.60$ & $0.40-0.40$ & $0.00-0.00$ \\
\pm 20\% perturbation of $M$ & & & & $0.00-0.00$ & $1.00-1.00$ \\
(1) Sinking of ungrazed cells & 1.00 & $0.00-0.00$ & $0.00-0.00$ & 0.00 & $0.45-0.27$ \\
(2) Herbivorous food web & 0.80 & $0.44-0.66$ & $0.16-0.15$ & $0.39-0.58$ & $0.17-0.08$ \\
(3) Multivorous food web & 0.35 & $0.52-0.78$ & $0.51-0.45$ & $0.32-0.48$ & $0.08-0.07$ \\
(4) Microbial food web & 0.10 & $0.20-0.30$ & $0.83-0.79$ & $0.09-0.14$ & $0.04-0.01$ \\
Microbial food web & 0.10 & $0.60-0.90$ & $0.68-0.58$ & $0.28-0.41$ & $0.00-0.00$ \\
(5) Microbial loop & 0.00 & $0.00-0.00$ & $1.00-1.00$ & $0.00-0.00$ & 0.00 \\
Microbial loop & 0.00 & $0.80-1.00$ & $0.68-0.52$ & $0.32-0.48$ & $0.00-0.00$ \\
\hline
\end{tabular}

DOC between 0.1 and 0.5 of net particulate phytoplankton production (Jumars et al. 1989), values of $R_{\mathrm{L}} / P_{\mathrm{T}}$ (Table 4 ) were set at $0.20,0.10$, and 0.03 for pathways 2 through 4 , respectively. Resulting estimates of $R_{\top} / P_{\uparrow}, F_{\mathrm{T}} / P_{\mathrm{T}}$ and $D_{\mathrm{T}} / P_{\top}$ are given in Table 4 . These account for $\mathrm{r}^{2}=0.86$ of the variance of corresponding values in Table 2. Given that the model without $R_{\mathrm{L}} / \mathrm{P}_{\mathrm{T}}\left(\mathrm{r}^{2}=\right.$ 0.83 , previous paragraph) accounts for almost as much variance as the model with $R_{\mathrm{L}} / P_{\mathrm{T}}$, the rule of parsimony dictates to use Eqs. (18), (22), (24) \& (25) in the remainder of this paper. In other words, addition of euphoticzone remineralization of large-size primary production does not significantly improve the model, whose purpose is to determine the partitioning of phytoplankton production among 3 broad carbon fluxes.

In order to assess the effects of natural variability on the model, estimates of $R_{\mathrm{T}} / P_{\mathrm{T}}, F_{\mathrm{T}} / P_{\mathrm{T}}, D_{\mathrm{T}} / P_{\mathrm{T}}$ were computed for values of $P_{\mathrm{L}} / P_{\mathrm{T}}$ and $M 20 \%$ smaller and larger than those used above. Results are given in Table 5 . The relatively small variability in carbon flux and $r^{2}$ values, in spite of the $40 \%$ perturbation of $P_{\mathrm{L}} / P_{\mathrm{T}}$ and $M$. shows that the model is quite robust with respect to natural variability.

Fig 3 illustrates the responses of $R_{\mathrm{T}} / P_{\mathrm{T}}, F_{\mathrm{T}} / P_{\mathrm{T}}$, and $D_{\mathrm{T}} / P_{\mathrm{T}}$ to the combined effects of $P_{\mathrm{L}} / \mathrm{P}_{\mathrm{T}}$ and $M$, computed from Eqs. (18), (22) \& (24) with constants $k_{\mathrm{L}}=1.0$ and $k_{\mathrm{S}}=0.4$. The 5 biogenic carbon pathways are located on the figure according to their $P_{\mathrm{L}} / P_{\mathrm{T}}$ and $M$ coordinates (Tables 2 \& 3 ). Fig 3 shows that $R_{\mathrm{T}} / P_{\mathrm{T}}$ is almost independent from $M$. This is because of the relatively low $k_{\mathrm{S}}$ value and the assumption that $R_{\mathrm{T}} \approx R_{\mathrm{S}}$ (Eq. 10). In contrast, $F_{\mathrm{T}} / P_{\mathrm{T}}$ and $D_{\mathrm{T}} / P_{\mathrm{T}}$ depend on both $P_{\mathrm{L}} / P_{\mathrm{T}}$ and $M$. As already evident from Tables $2 \& 3$, the 5 pathways are monotonically ordered along the abscissa $\left(P_{\mathrm{L}} / P_{\mathrm{T}}\right)$, but they respond in non-monotonic fashion to $M$ (ordinate). 


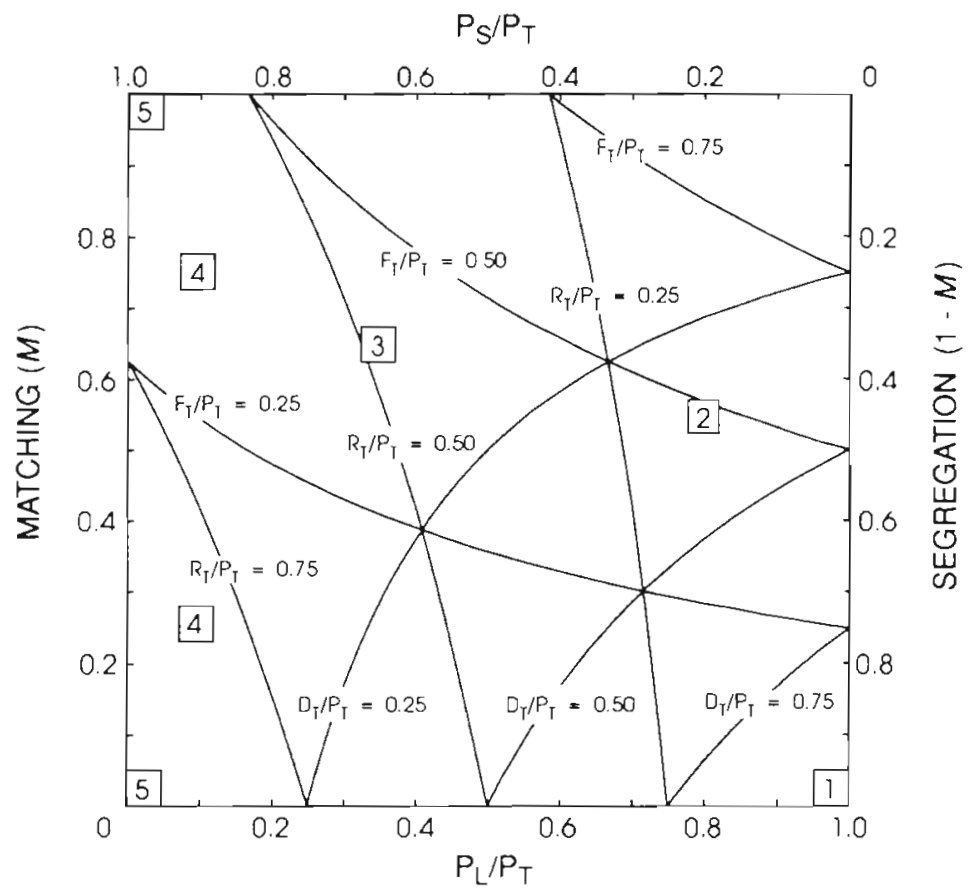

Fig. 3. Three fluxes of biogenic carbon, 1.e. remineralization within the euphotic zone $(R)$, food-web transfer $(F)$, and downward POC export $(D)$, plotted as functions of the size structure of primary production $\left(P_{L} / P_{T}\right.$ or $\left.P_{\mathrm{S}} / P_{\mathrm{T}}\right)$ and the matching $(M$, or segregation $1-M)$ between primary production and grazing. $P_{\mathrm{L}} / P_{\mathrm{T}}, P_{\mathrm{S}} / P_{\mathrm{T}}$ : shares in total primary production $\left(P_{\mathrm{T}}\right)$ of large and small phytoplankton $\left(P_{\mathrm{L}}\right.$ and $\left.P_{S}=P_{\mathrm{T}}-P_{\mathrm{L}}\right)$, respectively; $M$ is given on a scale of 0 (no matching) to 1 (perfect match). $R_{1} F$, and $D$ are expressed as proportions of $P_{\mathrm{T}}$. 1sopleths are plotted for values of $R_{\mathrm{T}} / P_{\mathrm{T}}$, $F_{T} / P_{T}$, and $D_{T} / P_{\mathrm{T}}=0.25,0.50$, and 0.75 . At any point 1 in the diagram, $R_{\mathrm{T}} / P_{\mathrm{T}}$ $+F_{\mathrm{T}} / P_{\mathrm{T}}+D_{\mathrm{T}} / P_{\mathrm{T}}=1$. Computed from Eqs. (18), (22) \& (24), with constants $k_{\mathrm{L}}=1.0$ and $k_{\mathrm{S}}=0.4$. The 5 biogenic carbon pathways (identified by num.bers 1 to 5, as in Fig. 1 and Tables 2 \& 3) are positioned according to the $P_{L} / P_{\mathrm{T}}$ and $M$ characteristics listed in Table 2

\section{HYDRODYNAMIC CONTROL OF BIOGENIC CARBON PATHWAYS}

The 2 axes of Fig. $3\left(P_{\mathrm{I}} / P_{\mathrm{T}}\right.$ and $\left.M\right)$ are under hydrodynamic control. Concerning the abscissa $\left(P_{\mathrm{L}} / P_{\mathrm{T}}\right)$. hydrodynamic conditions that favour high $P_{T}$ also lead to high $P_{\mathrm{L}} / P_{\mathrm{T}}$ (Fig. 2). Primary production is generally enhanced at spatio-temporal transitions between 2 types of segregation (e.g. Legendre et al. 1986). Such transitions correspond to transient matching of factors whose segregation otherwise limits phytoplankton production. In oceans, strong vertical mixing generally causes light limitation, whereas prolonged stratification results in nutrient limitation. Thus, the mechanism. that generally controls total phytoplankton production is the alternation, in time or/and space, from destabilized condition to vertical stratification of the water column (e.g Mann \& Lazier 1991). Legendre (1981) proposed to characterize the phytoplankton production potential of marine ecosystems by their frequency of destabilization-stabilization of the water column, defined as the number of sequences of vertical mixing/stabilization per unit time. According to Legendre (1981), a near-zero frequency identifies systems seldom destabilized or stabilized, whereas upwelling conditions tend to be near the upper limit of destabilization-stabilization (i.e spatio-temporal coexistence of the 2 hydrodynamic conditions). It follows that the abscissa of Fig. $3\left(P_{\mathrm{L}} / P_{\mathrm{T}}\right)$ likely corresponds to a positive gradient in the frequency of destabilizationstabilization of the water column (Fig. 4a).

Concerning the ordinate of Fig. 3, actual values of $M$ and the hydrodynamic conditions that control the matching between primary production and grazing processes are not well known. (1) Massive sinking of ungrazed phytoplankton may occur following blooms of large cells, when grazing pressure is very low (hence $M=0$ ). This is observed, for example, when the bloom is caused by rapid stabilization of a water column that has been deeply mixed for a long period (e.g. first stages of the spring bloom in the North Atlantic, at a time when mesozooplankton are still overwintering at depth; Parsons \& Lalli 1988) or sudden injection of nutrients in mutrient-depleted surface waters (e.g. episodic blooms of large phytoplankton at the bottom of the euphotic zone in oligotrophic oceanic waters, where large grazers are mostly absent; Goldman 1988, 1993). Thus, the sudden release of factor(s) that limited phytoplankton production may cause low matching between enhanced production of large phytoplankton and herbivorous grazing, hence sinking of ungrazed cells. (2) The herbivorous food web requires spatio-temporal coincidence between enhanced production of large phytoplankton and the presence of herbivores, hence relatively high $M$. This occurs when conditions that favour the production of large phytoplankton persist on a time scale which is compatible with the response time of their grazers (e.g. late stages of the spring bloom in the North Atlantic, which coincide with presence of mesozooplankton in surface waters; Cushing 1989). (3) In the multivorous food web, there is production of both large and small phytoplankton and coexistence of grazing by large and small zooplankton, hence higher $M$ than in the herbivorous web. A favourable condition is the alternation between vertical stability and moderate mixing (e.g. subarctic North Pacific, where it has been suggested that, as a consequence of shallow winter mixing, micro- and mesozooplankton grazers never 

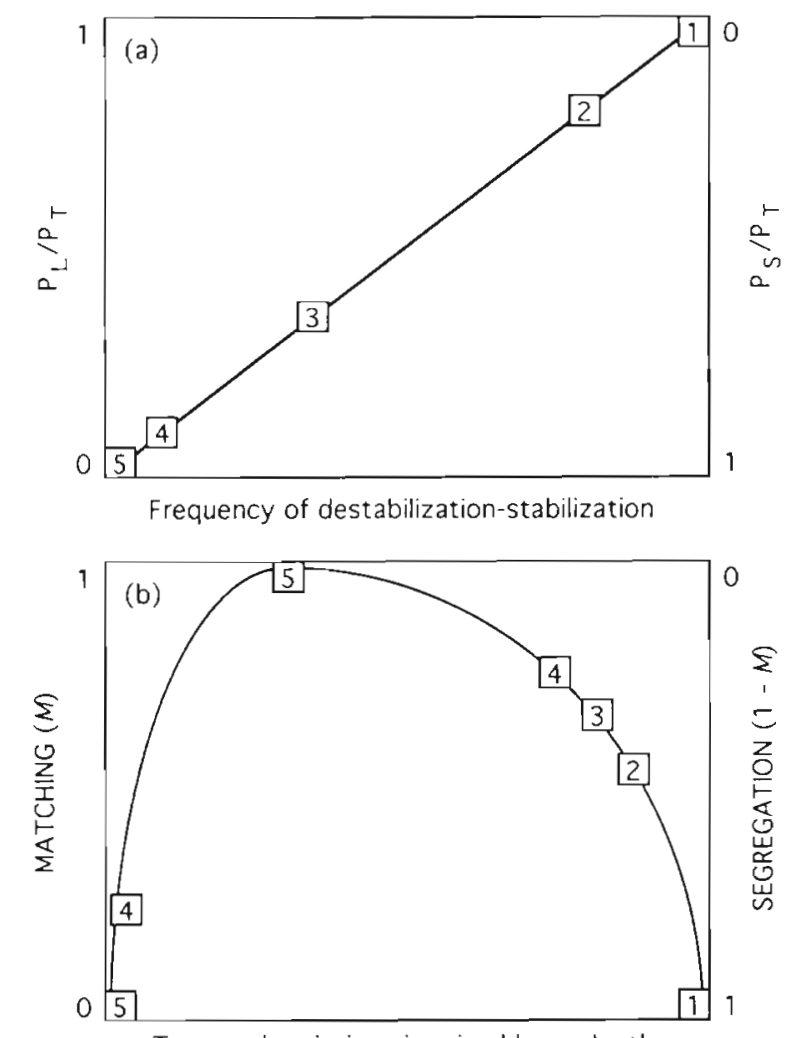

$z_{m(\min )}$

$\overline{z_{m}(\max )}$

$\frac{z_{m}(\min )}{z_{c r}}$

Temporal variations in mixed layer depth

Fig. 4. General relationships between the food-web and hydrodynamic factors that control biogenic carbon pathways. (a) Size structure of primary production $\left(P_{\mathrm{L}} / P_{\mathrm{T}}\right.$ or $P_{\mathrm{S}} / P_{\mathrm{T}}$; abscissa in Fig. 3) plotted as a function of the frequency of stabilizatıon-destabilization of the water column. (b) Matching $(M)$ or segregation $(1-M)$ between primary production and grazing (ordinate in Fig. 3) plotted as a function of temporal variations in depth of the surface mixed layer $\left(z_{m}\right)$, expressed in terms of the ratio of minimum to maximum mixed layer depth (ratios $z_{\mathrm{m}(\mathrm{mm})} / z_{\mathrm{m} / \max }=1$ characterize steady conditions and ratios < 1 correspond to alternation between mixing and stability) and the ratio of minimum mixed layer depth to critical depth (when ratios $z_{\text {mimin }} / z_{c r} \leq 1$, there is net growth of phytoplankton in $z_{11}$ and, when ratios $>1$, there is no net growth). The 5 pathways (identified by numbers 1 to 5 , as in Figs. $1 \& 3$ and Tables $2 \& 3$ are positioned according to the values of (a) $P_{\mathrm{L}} / P_{\mathrm{T}}$ and (b) $M$ listed in Table 2

lose control of production of small and large phytoplankton, respectively; Miller et al. 1991). (4) The microbial food web is generally encountered, as mentioned above, under conditions of either prolonged stability (e.g. oligotrophic tropical waters) or continuous deep mixing (e.g. winter at mid-latitudes), these 2 types of environment being thus characterized by steady hydrodynamics. Under the first condition, primary production operates on a low supply of regener- ated nutrients, whereas the second leads to light limitation of phytoplankton. The 2 types of limitation generally favour the production of small instead of large phytoplankton (e.g. Kirk 1986, Raven 1986). Under stable conditions, there is often tight coupling between the production of small phytoplankton and their grazing by microzooplankton $(M=0.75)$, because the latter have doubling rates that are similar to those of small phytoplankton (e.g. Sheldon et al. 1992, Riegman et al. 1993) This is presumably not the case when mixing is strong ( $M=0.25$ ). (5) In the microbial loop, net (vs gross) phytoplankton production is very low or even nul]. The first situation has been observed in oligotrophic tropical waters $(M=1)$, where the dominance of heterotrophic bacteria over phytoplankton has been interpreted as either a typical (Cho \& Azam 1990) or a transient condition (Rassoulzadegan 1990). The second case occurs above the polar circle during winter (no solar radiation during several months), where all processes in the deeply mixed water column $(M=0)$ are heterotrophic.

The brief review of grazing in the 5 biogenic carbon pathways suggests that there is a window in temporal variations in depth of the surface mixed layer within which the matching between primary production and grazing $(M)$ is high and outside which segregation (1 $M)$ prevails. This is similar to the 'optimal environmental window' proposed by Cury \& Roy (1989) for the relationship between annual fish recruitment (Peruvian anchoveta, Pacific sardine, West African sardines and sardinellas) and Ekman-type upwelling, where vertical advection, inputs of allochthonous nutrients and turbulence are related to wind speed. They found that recruitment is low during both weak upwelling (nutrient limited primary production) and strong upwelling (low matching between food and larval patches) and is optimal under moderate upwelling (wind speeds ca 5 to $6 \mathrm{~m} \mathrm{~s}^{-1}$ ). Thus, in Fig. 3, the matching between primary production and grazing would be high under conditions of prolonged moderate mixing (pathways 2, 3, and 4-5 with high $M$ ). Conversely, low matching would occur in areas and at times (pathway 1 ) when rapid stratification of a deeply mixed water column does not allow mesozooplankton to track the enhanced phytoplankton production, hence accumulation of biomass (called a bloom; see Legendre 1990) followed by massive sinking of large cells. Low matching would also occur (pathways 4 and 5 with low $M$ ) in waters where contacts between autotrophic or heterotrophic producers and their microzooplankton grazers are reduced because of very high turbulence (e.g. deep winter mixing). The responses of biogenic carbon pathways to temporal variations in depth of the surface mixed layer are therefore nonlinear (Fig. 4b), all the more so because the characteristics of zooplankton grazers vary among groups, 
from organisms that multiply very fast and thus often track phytoplankton (e.g. protozoan microzooplankton and large microphages) to mesozooplankton copepods that overwinter in deep waters and reproduce once or twice a year. It follows that the ordinate of Fig. $3(M)$ likely reflects nonmonotonic responses to temporal variations in depth of the surface mixed layer (Fig. 4b). The latter is defined here by the ratios of minimum to maximum mixed layer depth $\left(z_{\mathrm{m}(\operatorname{mnn})} / z_{\mathrm{m}(\max )}\right)$ and of minimum mixed layer depth to critical depth $\left(z_{\mathrm{m}(\mathrm{mun})} / z_{\mathrm{cri}}\right.$ Sverdrup $1953 ; z_{\mathrm{cr}}=E_{0} / k E_{c}$, where $E_{0}$ is the irradiance at the sea surface, $k$ is the coefficient of diffuse light attenuation, and $E_{c}$ is the compensation irradiance for phytoplankton photosynthesis).

In Fig. 5, the 5 biogenic carbon pathways and the isopleths for $R_{\mathrm{T}} / P_{\mathrm{T}}, F_{\mathrm{T}} / P_{\mathrm{T}}$, and $D_{\mathrm{T}} / P_{\mathrm{T}}$ are positioned by reference to the above 2 hydrodynamics axes (frequency of destabilization-stabilization and temporal variations in depth of the surface mixed layer). The figure indicates that temporal variations in depth of the surface mixed layer do not influence $R_{\mathrm{T}} / P_{\mathrm{T}}$ much (isopleths almost parallel to the ordinate) but that they largely govern $F_{\mathrm{T}} / P_{\mathrm{T}}$ and $D_{\uparrow} / P_{\Upsilon}$. The ordering of pathways in Fig. 5 is almost monotonic along both axes, which was not the case on the food-web axes $\left(P_{\mathrm{L}} / P_{\mathrm{T}}\right.$ and $M ;$ Fig 3 ). This suggests that the ultimate control of biogenic carbon export from the euphotic zone is exerted by hydrodynamic factors, through the proximal agency of food-web characteristics (Fig. 4).

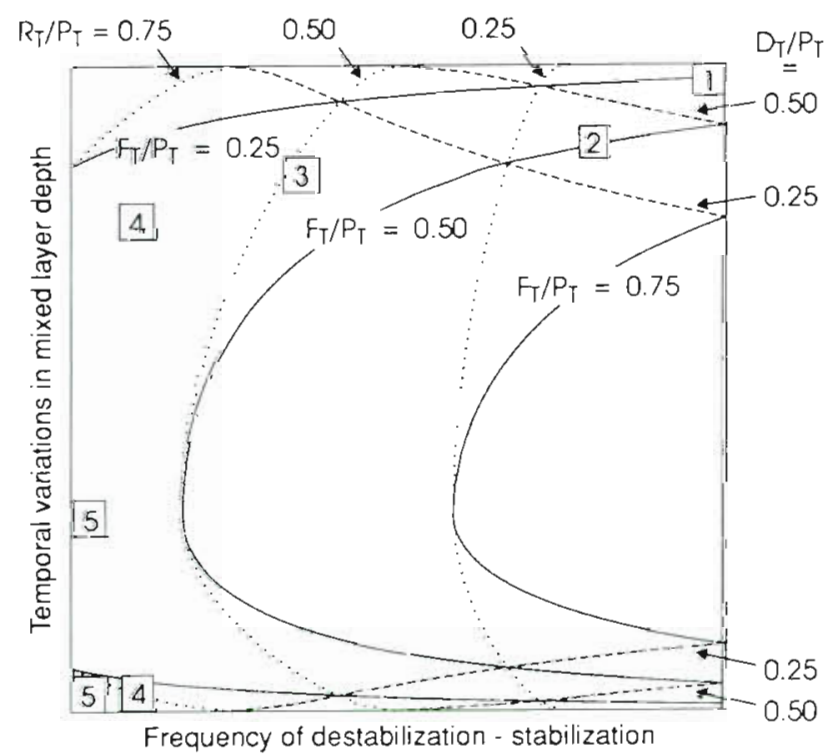

Fig. 5. The 5 biogenic carbon pathways and isopleths for the 3 fluxes of biogenic carbon $\left(R_{\mathrm{T}} / P_{\mathrm{T}}, F_{\mathrm{T}} / P_{\mathrm{T}}\right.$, and $D_{\mathrm{T}} / P_{\mathrm{T}}$ identified as in Fig. 3) positioned by reference to the 2 hydrodynamics axes defined in Fig. 4 (frequency of stabilization-destabilization of the water column and temporal variations in depth of the surface mixed layer). Transformed from Fig. 3 using the 2 relationships in Fig. 4

\section{HYDRODYNAMIC CONTROL OF BIOGENIC CARBON EXPORT FROM THE EUPHOTIC ZONE}

Fig. 6 illustrates the response of $E_{T} / P_{T}$ to the combined effects of (Fig 6a) $P_{\mathrm{L}} / \mathrm{P}_{\mathrm{T}}$ and $M$, computed from Eq. (25) with constants $k_{\mathrm{L}}=1.0$ and $k_{\mathrm{S}}=0.4$, and (Fig 6b) the frequency of destabilization-stabilization
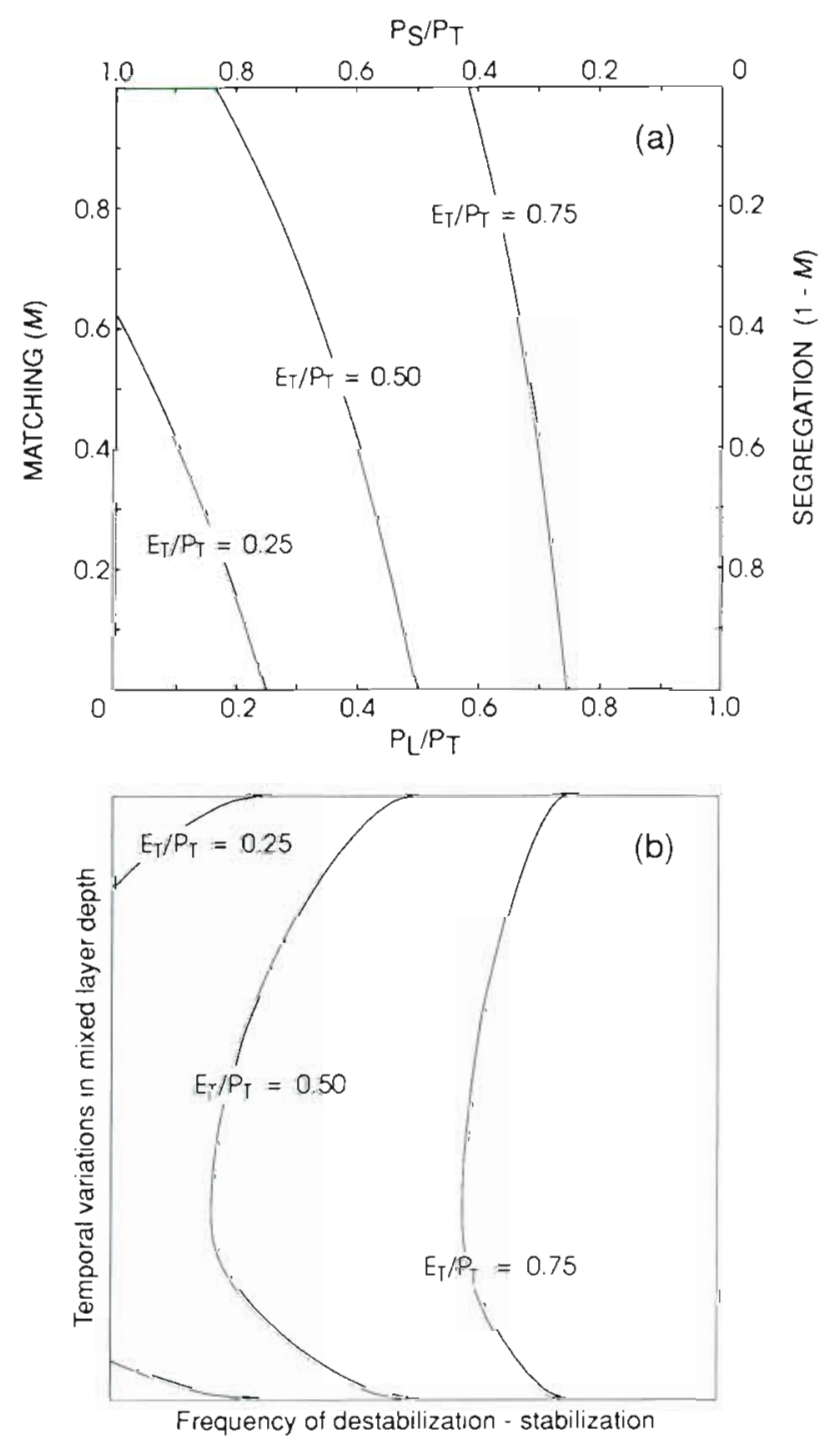

Fig. 6. Proportion of total primary production $\left(P_{\mathrm{T}}\right)$ exported from the euphotic zone (by food-web transfer and downward POC flux, i.e. $E_{\mathrm{T}}=F_{\mathrm{T}}+D_{\mathrm{T}}$ ) as a function of (a) the abscissa and ordinate used in Fig. 3, i.e. size structure of primary production $\left(P_{\mathrm{L}} / P_{\mathrm{T}}\right.$ or $\left.P_{\mathrm{S}} / P_{\mathrm{T}}\right)$ and the matching $(M)$ or segregation (1$M$ ) between primary production and grazing, and (b) the 2 hydrodynamics axes defined in Fig. 4, i.e. frequency of stabilization-destabilization of the water column and temporal variations in depth of the surface mixed layer Isopleths plotted for values of $E_{\mathrm{T}} / P_{\mathrm{T}}=0.25,0.50$, and 0.75 : (a) computed from Eq. (25), with constants $k_{\mathrm{L}}=1.0$ and $k_{\mathrm{S}}=0.4$, and (b) transformed using the 2 relationships in Fig. 4 
and temporal variations in depth of the surface mixed layer. Because $E_{\mathrm{T}} / P_{\mathrm{T}}=1-R_{\mathrm{T}} / P_{\mathrm{T}}$, the isopleths for $E_{\mathrm{T}} / P_{\mathrm{T}}=$ $0.25,0.50$ and 0.75 in Fig. $6 \mathrm{a}, \mathrm{b}$ are the same as those for $R_{\mathrm{T}} / P_{\mathrm{T}}=0.75,0.50$ and 0.25 in Figs. 3 \& 5, respectively. Fig. 6 shows that total export relative to primary production $\left(E_{T} / P_{\mathrm{T}}\right)$ is almost independent from $M$ or from temporal variations in depth of the surface mixed layer (isopleths almost parallel to the ordinates). This is because, in Eq. (25), $M$ is multiplied by the constant $k_{\mathrm{S}}=0.4$, which is relatively small. Thus, the degree of matching $(M)$ between primary production and grazing. which is controlled by temporal variations in depth of the surface mixed layer (Fig. 4b), does not play a major role in determining total export from the euphotic zone. In contrast, $E_{\mathrm{T}} / P_{\mathrm{T}}$ is a direct function of $P_{\mathrm{L}} / P_{\mathrm{T}}$ or of the frequency of destabilization-stabilization (regular gradient along the abscissae) and, hence, of total primary production (Fig. 2).

The proportion of total export channelled through the food web $\left(F_{\mathrm{T}} / E_{\mathrm{T}}\right)$ is:

$$
F_{\mathrm{T}} / E_{\mathrm{T}}=\left(F_{\mathrm{T}} / P_{\mathrm{T}}\right) /\left(E_{\mathrm{T}} / P_{\mathrm{T}}\right)
$$

which, using Eq. (24), gives:

$$
F_{\top} / E_{\top}=\left[M /\left(E_{\mathrm{T}} / P_{\mathrm{T}}\right)\right]\left[k_{\mathrm{S}}+\left(k_{\mathrm{L}}-k_{\mathrm{S}}\right)\left(P_{\mathrm{L}} / P_{\top}\right)\right]
$$

and, because $E_{\Upsilon}=F_{\Upsilon}+D_{\Upsilon}$, the proportion of total export channelled through the downward POC flux $\left(D_{\top} / E_{\top}\right)$ is:

$$
D_{\top} / E_{\Upsilon}=1-F_{\top} / E_{\mathrm{T}}
$$

Eq. (38) shows that, for a given value of $P_{\mathrm{L}} / P_{\mathrm{T}}, F_{\mathrm{T}} / E_{\mathrm{T}}$ is a direct function of $M$ and an inverse function of $E_{\top} / P_{\mathrm{T}}$. The reverse is true for $D_{\uparrow} / E_{\uparrow}$ (Eq. 39). Thus, temporal variations in depth of the surface mixed layer, which are instrumental in determining $M$ (Fig. 4b), may play a major role in partitioning total export from the euphotic zone between food-web transfer and sinking of POC. Export to the food web is significant for marine resources (which are part of the long-lived organic carbon) and export to depth may contribute to the regulation of climate change (by sequestering sinking biogenic carbon)

Combining Figs. 1 \& 3 shows that the pathways from marine primary production to carbon pools are largely determined by 2 food-web characteristics, i.e. the size structure of primary production $\left(P_{\mathrm{L}} / P_{\mathrm{T}}\right)$ and the degree of matching between primary production and grazing $(M)$. These 2 characteristics are under hydrodynamic control, i.e. $P_{\mathrm{L}} / P_{\mathrm{T}}$ responds to the delivery of mechanical energy to the euphotic zone (Fig. 4 a) and $M$ reflects temporal variations in depth of the surface mixed layer as defined in Fig. $4 \mathrm{~b}$. The latter mechanism has little influence on total export from the euphotic zone (Fig. 6), but it may play a major role in partitioning total export between the food web and downward export fluxes (Eqs. 38 \& 39). In addition, temporal variations in depth of the surface mixed layer appear to strongly influence both food-web and downward POC export (Fig 5). It follows that total export from the euphotic zone is a function of the delivery of mechanical energy and that the type of export (i.e. food-web vs sinking) is also determined by temporal variations in depth of the surface mixed layer

\section{DETERMINING BIOGENIC CARBON FLUXES USING FOOD-WEB OR HYDRODYNAMIC CHARACTERISTICS}

The equations in the present paper can be used to compute the partitioning of phytoplankton production among 3 biogenic carbon fluxes, i.e. euphotic-zone remineralization $(R)$, food-web transfer $(F)$, and downward POC flux $(D)$. In order to do so, estimates of 2 food-web characteristics $\left(P_{\mathrm{L}} / P_{\mathrm{T}}\right.$ and $\left.M\right)$ and of 2 constants $\left(k_{\mathrm{L}}\right.$ and $\left.k_{\mathrm{S}}\right)$ are required. Values of $k_{\mathrm{L}}$ and $k_{\mathrm{S}}$ were derived, above, from published data. $P_{\mathrm{L}} / P_{\mathrm{T}}$ is relatively easy to determine at sea, but estimation of $M$ under field conditions has not been attempted yet. Alternatively, the 2 food-web characteristics can be replaced, in Eqs. (18), (22), (24), (25), (38) \& (39), by hydrodynamic factors for which values may be more readily available or easier to estimate or model, i.e. the frequency of stabilization-destabilization of the water column (Fig. 4a) and temporal variations in depth of the surface mixed layer (Fig $4 \mathrm{~b}$ ). In this respect, future work should aim at quantifying the 2 relationships in Fig. 4 This quantification should include not only equations that relate food-web characteristics to hydrodynamic factors but also the spatiotemporal scales at which these equations apply. Relationships described in the present paper provide a simple framework for investigating the food-web and hydrodynamic controls of biogenic carbon fluxes in oceans. These controls were shown to be significant for both marine resources and climate change.

Acknowledgements. The authors thank P. Legendre, R. B. Rivkin, J. E. Tremblay, and anonymous revewers for useful comments and suggestions, J. E. Tremblay for providing the values used in Fig. 2, and B. LeBlanc for comments and for drafting figures. Grants from the NATO International Scientific Exchange Programmes (F.R. and L.L.), the Natural Sciences and Engineering Research Council of Canada (L.L.), the EEC MAST III Project MAS3-CT95-0016-MIEDEA and a Killam Research Fellowship (L.L.) were instrumental in the completion of the work. This is a contribution to the programmes of GIROQ (Groupe interuniversitaire de recherches océanographiques du Québec) and of the Laboratoire d'Écologie du Plancton Marın. 


\section{LITERATURE CITED}

Berman T, Townsend DW, El Sayed SZ, Trees CC, Azov Y (1984) Optical transparency, chlorophyll and primary productivity in the eastern Mediterranean near the Israeli coast. Oceanol Acta 7:367-372

Betzer PR, Showers WJ, Laws EA, Winn CD, DiTullio GR, Kroopnick PM (1984) Primary productivity and particle fluxes on a transect of the equator at $153^{\circ} \mathrm{W}$ in the Pacific Ocean. Deep Sea Res 31:1-11

Carlson CA, Ducklow HW, Michaels AF (1994) Annual flux of dissolved organic carbon from the euphotic zone in the northwestern Sargasso Sea. Nature 371:405-408

Childress JJ, Mickel TJ (1985) Metabolic rates of animals from the hydrothermal vents and other deep-sea habits. Bull Biol Soc Washington 6:249-260

Cho BC, Azam F (1988) Major role of bacteria in biogeochemical fluxes in the ocean's interior. Nature 332:441-443

Cho BC, Azam F (1990) Biogeochemical significance of bacterial biomass in the ocean's euphotic zone. Mar Ecol Prog Ser 63:253-259

Cole BE, Cloern JE, Alpine AE (1986) Biomass and productivity of three phytoplankton size classes in San Francisco Bay. Estuaries 9:117-126

Cury P, Roy C (1989) Optımal environmental window and pelagic fish recruitment success in upwelling areas. Can J Fish Aquat Sci 46:670-680

Cushing DH (1989) A difference in structure between ecosystems in strongly stratified waters and in those that are only weakly stratified. J Plankton Res 11:1-13

Eppley RW, Peterson BJ (1979) Particulate organic matter flux and planktonic new production in the upper ocean. Nature 282:677-680

Erga SR, Heimdal BR (1984) Ecological studies on the phytoplankton of Korsfjorden, western Norway. The dynamics of a spring bloom seen in relation to hydrographical conditions and light regime. J Plankton Res 6:67-90

Fasham MJR, Ducklow HW, McKelvie DS (1990) A nitrogenbased model of plankton dynamics in the oceanic mixed layer. J Mar Res 48:591-639

Fortier L, Le Fèvre J, Legendre L (1994) Export of biogenic carbon to fish and to the deep ocean: the role of large planktonic microphages. J Plankton Res 16:809-839

Glover HE, Campbell L, Prézelin BB (1986) Contribution of Synechococcus sp. to size-fractioned primary production in three water masses in the Northwest Atlantic Ocean. Mar Biol 91:193-203

Glover HE, Smith AE, Shapiro L (1985) Diurnal variatıon in photosynthetic rates: comparisons of ultraplankton with a larger phytoplankton size fraction. J Plankton Res 7 $519-535$

Goldman JC (1988) Spatial and temporal discontinuities of biological processes in pelagic surface waters. In: Rothschild BJ (ed) Toward a theory on biological-physical interactions in the world ocean. Kluwer, Dordrecht, p 273-296

Goldman JC (1993) Potential role of large oceanic diatoms in new primary production. Deep Sea Res 40:159-168

Gomes HDR, Goes JI, Parulekar AH (1992) Size-fractionated biomass, photosynthesis and dark $\mathrm{CO}_{2}$ fixation in a tropical oceanic environment. J Plankton Res 14:1307-1329

Hagström $A$, Azam $F$, Andersson A, Wikner $J$, Rassoulzadegan F (1988) Microbial loop in an oligotrophic pelagic marine ecosystem: possible roles of cyanobacteria and nanoflagellates in the organic fluxes. Mar Ecol Prog Ser 49:171-178

Hansen PJ (1991) Quantitative importance and trophic role of heterotrophic dinoflagellates in a coastal pelagial food web. Mar Ecol Prog Ser 73:253-261

Iverson RL (1990) Control of marine fish production. Limnol Oceanogr 35:1593-1604

Jochem FJ, Pollehne F, Zeitzschel B (1993) Productivity regime and phytoplankton size-structure in the Arabian Sea. Deep Sea Res 40:711-735

Jochem FJ, Zeitzschel B (1993) Productivity regime and phytoplankton size structure in the tropical and subtropical North Atlantic in spring 1989. Deep Sea Res 40: $495-519$

Joint IR, Owens NJP, Pomroy AJ (1986) Seasonal production of photosynthetic picoplankton and nanoplankton in the Celtic Sea. Mar Ecol Prog Ser 28:251-258

Joint IR, Pomroy A, Savidge G, Boyd P (1993) Size-fractionated primary productivity in the north-east Atlantic in May-July 1989. Deep Sea Res 40:423-440

Jumars PA, Penry DL, Baross JA, Perry MJ, Frost BW (1989) Closing the microbial loop: dissolved carbon pathway to heterotrophic bacteria from incomplete ingestion, digestion and absorption in animals. Deep Sea Res 36:483-495

Kiorboe T, Andersen KP. Dam HG (1990) Coagulation efficiency and aggregate formation in marine phytoplankton. Mar Biol 107:235-245

Kirchman DL, Lancelot C. Fasham MJR, Legendre L, Radach $G$. Scott M (1993) Dissolved organic matter in biogeochemical models of the ocean. In: Evans GT, Fasham MJR (eds) Towards a model of ocean biogeochemical processes. Springer-Verlag, Berlin, p 209-225

Kirk JTO (1986) Optical properties of picoplankton suspensions. In: Platt T, Li WKW (eds) Photosynthetic picoplankton. Can Bull Fish Aquat Sci 214:501-520

Krupatkina DK, Finenko ZZ, Shalapyonok AA (1991) Primary production and size-fractionated structure of the Black Sea phytoplankton in the winter-spring period. Mar Ecol Prog Ser 73:25-31

Kuparinen J (1987) Production and respiration of overall plankton and ultraplankton communities at the entrance to the Gulf of Finland in the Baltic Sea. Mar Biol 93: $591-607$

Lancelot C, Mathot S, Becquevort S, Dandois JM, Billen G (1993) Carbon and nitrogen cycling through the microbial network of the marginal ice zone of the Southern Ocean with particular emphasis on the northwestern Weddel Sea. In: Caschetto S (ed) Belgian Scientific Research Programme on the Antarctic. Scientific Results of Phase Two (10/1988-05/1992), Vol I, Plankton ecology and manne biogeochemistry. Belgian Science Policy Office, Brussels, p $1-190$

Legendre L (1981) Hydrodynamic control of marine phytoplankton production: the paradox of stability. In: Nihoul JCJ led) Ecohydrodynamics. Elsevier, Amsterdam, p $191-207$

Legendre L (1990) The significance of microalgal blooms for fisheries and for the export of particulate organic carbon in oceans. J Plankton Res 12:681-699

Legendre L (1996) The biological $\mathrm{CO}_{2}$ pump in seasonally icecovered waters. Proc NIPR Symp Polar Biol 9:61-74

Legendre L, Demers S, Lefaivre D (1986) Biological production at manne ergoclines. In: Nihoul JCJ (ed) Marine interfaces ecohydrodynamics. Elsevier, Amsterdam, p $1-29$

Legendre L, Gosselin M. Hirche HJ, Kattner G, Rosenberg G (1993) Environmental control and potential fate of sizefractionated phytoplankton production in the Greenland Sea $\left(75^{\circ} \mathrm{N}\right)$. Mar Ecol Prog Ser 98:297-313

Legendre L, Le Fèvre J (1991) From individual plankton cells 
to pelagic marine ecosystems and to global biogeochemical cycles. In: Demers S (ed) Particle analysis in oceanography. Springer-Verlag, Berlin, p. 261-300

Legendre L, Le Fèvre J (1992) Interactions between hydrodynamics and pelagic ecosystems: relevance to resource exploitation and climate change. S Afr J Mar Sci 12:477-486

Legendre L, Rassoulzadegan F (1995) Plankton and nutrient dynamacs in marine waters. Ophelia 41:153-172

Lessard EJ (1991) The trophic role of heterotrophic dinoflagellates in diverse marine environments. Mar Microb Food Webs 5:49-58

Longhurst AR, Bedo AW, Harrison WG, Head EJH, Sameoto DD (1990) Vertical flux of respiratory carbon by oceanic diel migrant biota. Deep Sea Res 37:685-694

Mann KH, Lazier JRN (1991) Dynamics of marine ecosystems. Bjological-physical interactions in the oceans. Blackwell, Boston

Margalef R (1978) Life-forms of phytoplankton as survival alternatives in an unstable environment. Oceanol Acta 1 493-509

Margalef R (1985) From hydrodynamic processes to structure (information) and from information to process. In: Ulanowicz RE, Platt $T$ (eds) Ecosystems theory for brological oceanography. Can Bull Fish Aquat Sci 213:200-220

Margalef R (1993) Teoría de los sistemas ecológicos, 2nd edn Publ Univ Barcelona, Barcelona

Michaels AF, Bates NR, Buesseler KO, Carlson CA, Knap AH (1994) Carbon-cycle imbalances in the Sargasso Sea Nature 372:537-540

Miller CB, Frost BW, Wheeler PA, Landry MR, Welschmeyer $N$, Powell TW (1991) Ecological dynamics in the subarctic Pacific, a possible iron-limited ecosystem. Limnol Oceanogr 36:1600-1615

Moloney CL, Field JG (1991) The size-based dynamics of plankton food webs. I. A simulation model of carbon and nitrogen flows. J Plankton Res 13:1003-1038

Moloney CL, Field JG, Lucas MI (1991) The size-based dynamics of plankton food webs. Il. Simulations of three contrasting southern Benguela food webs. J Plankton Res $13: 1039-1092$

Noji TT (1991) The influence of macrozooplankton on vertical particulate flux. Sarsia 76:1-9

Pace ML, Knauer GA, Karl DM, Martin J (1987) Primary production, new production, and vertical flux in the eastern Pacific Ocean. Nature 325:803-804

Parsons TR, Lalli CM (1988) Comparative oceanic ecology of the plankton communities of the subarctic Atlantic and Pacific Oceans. Occanogr Mar Biol A Rev 26:317-359

Rassoulzadegan F (1990) Marine protozooplankton and food webs. Zool Sci 7(Suppl): 189-196

Rassoulzadegan F (1993) Protozoan patterns in the AzamAmmerman's bacteria-phytoplankton mutualism. In Guerrero R, Pedrós-Alió C (eds) Trends in microbial

This article was submitted to the editor ecology. Spanish Society for Microbiology, Barcelona, p $435-439$

Raven JA (1986) Physiological consequences of extremely small size for autotrophic organisms in the sea. In: Platt $\tau$, Li WKW (eds) Photosynthetic picoplankton. Can Bull Fish Aquat Sci 214:1-70

Riegman R, Kuipers BR, Noordeloos AAM, Witte HJ (1993) Size-differential control of phytoplankton and the structure of plankton communities. Neth J Sea Res 31:255-265

Rivkin $R$, Legendre L, Deibel D, Tremblay JE, Klein B, Crocker K, Roy S, Silverberg N, Lovejoy C, Mesplé F, Romero N, Anderson MR, Matthews P, Savenkoff C, Vézina $A_{1}$ Therriault JC, Wesson $J$, Bérubé $C$, Ingram RG (1996) Vertical fluxes of biogenic carbon in oceans: is there food web control? Science 272:1163-1166

Roy S, Harris RP, Poulet SA (1989) Inefficient feeding by Calanus helgolandicus and Temora longıcornis on Coscinodiscus wailesii: quantitative estimation using chlorophyll-type pigments and effects on dissolved free amino acids. Mar Ecol Prog Ser 52:145-153

Sharp JH (1984) lnputs into microblal food chains. In: Hobbie JE, Williams, PJleB (eds) Heterotrophic activity in the sea. Plenum, New York, p 101-120

Sheldon RW, Rassoulzadegan F, Azam F, Berman T, Bezanson DS, Bianchi $M$, Bonın D. Hagström $\AA$, Laval-Peuto $M$, Neveux J, Raimbault P, Rivier A, Sherr BF, Sherr EB, Van Wambeke F, Wikner J, Wood AM, Yentsch CM (1992) Nano- and picoplankton growth and production in the Bay of Villefranche-sur-Mer (NW Mediterranean). Hydrobiologia 241:91-106

Siebenaller JF, Somero GN (1989) Biochemical adaptation to the deep-sea. Crit Rev Aquat Sci 1:1-25

Smoluchovski, $M$ von (1918) Versuch einer mathematischen Theorie der Koagulationskinetik kolloider Lösungen. Z Physik Chemie 92:129-168

Stockton WL. De Laca TE (1982) Food falls in the deep sea: occurrence, quality and significance. Deep Sea Res 29: $157-169$

Sverdrup HU (1953) On conditions for the vernal blooming of phytoplankton. J Cons Perm Int Explor Mer 18:287-295

Torres JJ, Childress JJ (1985) Respiration and chemical composition of the bathypelagic euphausiid Bentheuphausia amblyops. Mar Biol 87:267-272

Tremblay JE, Klein B, Legendre L, Rivkin RB, Therriault JC (in press) Estimating the vertical fluxes of biogenic carbon in oceans based on phytoplankton size structure. Limnol Oceanogr

Wassmann P (1990) Relationship between primary and export production in the boreal coastal zone of the North Atlantic. Limnol Oceanogr 35:464-471

Wood AM, Rai H, Garnier J, Kairesalo T, Gresens S, Orive E, Ravail B (1992) Practical approaches to algal excretion. Mar Microb Food Webs 6:21-38

Manuscript first received: April 15, 1996

Revised version accepted: November 1, 1996 